\title{
Developmental Study of Distortion Errors in Affricative, Fricative, and Liquid Sounds
}

\author{
Mi Jin Kima, Eun Joo Ryu ${ }^{\mathrm{a}, \mathrm{b}}$, Ji-Wan $\mathrm{Ha}^{\mathrm{a}, \mathrm{c}}$ \\ ${ }^{a}$ Department of Speech and Language Pathology, Graduate School of Rehabilitation, Daegu University, Gyeongsan, Korea \\ ${ }^{b}$ Department of Speech-Language Pathology and Audiology, Uiduk University, Gyeongju, Korea \\ 'Department of Speech Pathology, Daegu University, Gyeongsan, Korea
}

\author{
Correspondence: Ji-Wan $\mathrm{Ha}, \mathrm{PhD}$ \\ Department of Speech Pathology, Daegu \\ University, 201 Daegudae-ro, Jillyang-eup, \\ Gyeongsan 38453, Korea \\ Tel: +82-53-850-4327 \\ Fax: +82-53-850-4329 \\ E-mail: jw-ha@daegu.ac.kr
}

This work was supported by the Ministry of Education of the Republic of Korea and the National Research Foundation of Korea (NRF2019S1A5A2A03054267).

Received: April 20, 2020

Revised: May 4, 2020

Accepted: May 4, 2020

\begin{abstract}
Objectives: This study attempted to examine the developmental process in detail by comparing the distortion error rates and error patterns of affricative, fricative, and liquid sounds; which are later developing speech sounds in Korean and exhibit many errors. Method: A Urimal Test of Articulation and Phonology 2 (UTAP2) word-level test was performed on 556 typically developing children aged 2-7 years. We compared the error rates and error patterns in words containing affricate, fricative, and liquid sounds among age groups. Results: First, the error rates decreased significantly in older age groups and there were significant differences depending on age. As age increased, error rates decreased in the order of initial $\mathrm{I} / \mathrm{l}, \mathrm{tt} * /, / \mathrm{tc} /$, /tch/, final $/ \mathrm{l} /, / \mathrm{s} * /$, and $/ \mathrm{s} /$. Second, regarding error patterns, the affricatives began with substitution and developed through the stopping process. The fricatives developed through the process of substitution and interdentalization/dentalization, and the liquids developed through omission and weakening. Conclusion: The results of this study showed the development and acquisition process of speech sounds by analyzing error patterns; focusing on distortion errors of affricative, fricative, and liquid sounds in a sufficient amount of data from each groups. This will provide useful information to guide a gradual approach towards a target phoneme in the intervention of children with speech sound disorders.
\end{abstract}

Keywords: Affricative sound, Fricative sound, Liquid sound, Distortion, Speech error rate, Speech error patterns
정확한 말소리 산출은 말소리에 주의를 기울이고 지각할 수 있 는 청지각능력, 지각된 말소리를 이해하고 저장, 인출할 수 있는 인 지능력, 특정 말소리를 다른 말소리와 변별할 수 있는 음운능력, 산 출을 위해 조음운동을 계획하고 실행하는데 필요한 신경운동능력 과 같은 여러 요인들이 복합적으로 관여한다. 이처럼 복잡한 과정 을 기반으로 하는 만큼 말소리 발달은 단기간에 이루어질 수 없으 며, 유아기부터 학령전기까지 지속적이고 점차적으로 그 과정이 진 행된다. 말소리 발달에 대한 정보는 중요한데, 그 이유는 말소리장 애를 진단하고 중재의 방향을 정하는 데에 결정적 기준이 되기 때 문이다.

말소리 산출능력은 같은 연령 내에서도 개인차가 크다(Koch, 2018). 따라서 신뢰할 수 있는 말소리 습득연령을 파악하기 위해 다
양한 연구가 꾸준히 진행되어 왔다. 27 개 언어의 말소리 습득연령 을 비교 분석한 McLeod와 Crowe (2018)의 연구를 살펴보면, 75$85 \%$ 의 아동이 바르게 산출한 연령은 $/ \mathrm{m}, \mathrm{n}, \mathrm{h}, \mathrm{p}, \mathrm{w}, \mathrm{d}, \mathrm{b}, \mathrm{f}, \mathrm{k}, \mathrm{g}, \mathrm{g} /$

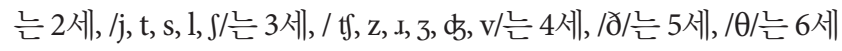
였고, $90-100 \%$ 의 아동이 바르게 산출한 연령은 $/ \mathrm{p} /$ 는 2 세, /b, m, d,

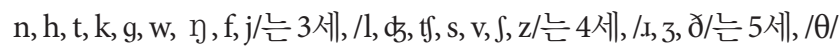
는 6세 였다. 이러한 연구를 통해 McLeod와 Crowe (2018)는 말소 리 습득에는 분명 개인차와 변이성이 존재하지만 습득연령에 있어 언어의 보편성을 확인할 수 있음을 언급하였다. 이러한 보편성은 우리나라 아동에서도 동일하게 관찰된다. 한국어의 경우 $75-94 \%$ 의 아동이 바르게 산출할 수 있는 숙달연령은 /ㅂ, 뻐, ㄴ, ᄃ, ㄸ, $\mathrm{E}, \mathrm{J}, \mathrm{T}, \mathrm{J}$, 히는 2 세에서 2 세 11 개월, / ㅈ, ㅉ, ㅊ, 씨는 3 세에서 
3 세 11 개월, / 시는 4 세에서 4 세 11 개월, /리는 5 세에서 5 세 11 개월 이고, 95-100\%가 산출할 수 있는 완전습득연령은 /표, ㅁ, 이는 2 세에서 2세 11개월, /ㅂ, 빠, , ㅌ/는 3세에서 3세 11개월, /ㄴ, T1, 디는 4 세에서 4 세 11 개월, /ᄀ, ㄱ, 즈, 짜는 5세에서 5세 11 개월, /시는 6세에서 6세 11개월로 보고되었다(Kim \& Shin, 2015). 이상 과 같은 선행연구들을 정리해보면 언어에 상관 없이 후기에 습득되 는 말소리는 조음방법적으로 어려운 소리들이며, 대표적으로 파찰 음, 마찰음, 유음을 들 수 있다. 이 말소리들은 산출이 어렵기 때문 에 습득연령이 늦고, 그 만큼 오류도 많다.

말소리장애 분야에서 파찰음, 마찰음, 유음의 발달과정을 정확 하게 파악하는 것은 매우 중요하다. 일반 아동도 조음산출이 쉽지 않은 만큼 말소리장애 아동 대부분이 이 말소리들에서 많은 오류 를 보이는데, 이에 대해서는 발달적 오류패턴에서 해당 말소리들의 오류가 차지하는 비중을 확인해보면 더욱 명확히 알 수 있다(Kim, Shin, Kim, \& Ha, 2020). 앞에서도 언급하였듯이 말소리 산출능력 을 정확하게 파악하고 오류가 있을 경우 중재 방향과 순서를 정하 는 데에 일반 아동의 말소리 발달과정은 중요한 기준을 제공한다. 발달 연구는 습득 과정과 오류변화의 과정, 즉 얼마나 말소리를 정 확히 이해하는지, 그리고 어떻게 틀리는지의 두 가지 측면에서 접 근하는 것이 보편적이다.

우선 습득 측면의 발달과정을 살펴보면 파찰음의 경우 Oum (1986)은 3세에 75\%의 습득기준에 도달한다고 하였고, $\operatorname{Kim}$ (1996) 은 2세-3세에 출현하여 완전 습득연령이 4-5세 경이라고 하였다. 좀 더 구체적으로 Kim과 Pae (2005)는 /ㅊ, ㅉ/는 3세 전반, / ㅈ/는 3세 후반 $75 \%$ 의 습득기준에 도달하고, 완전 습득연령은 4 세 전반이라 고 하였다. 일음절 수준에서 습득연령을 연구한 $\mathrm{Ha}, \mathrm{Kim}$ 과 $\mathrm{Pi}$ (2019)에서는 이와 다소 차이가 있는데, / ㅈ/는 2세 후반 75\% 이상, 3 세 후반 $90 \%$ 이상, /ㅊ, 짜/는 3세 후반 50\% 이상, 4세 전반 $75 \%$ 이 상, 5 세 전반 $90 \%$ 이상 산출이 가능하다고 하였다. 마찰음의 경우 Oum (1986)은 5세까지도 습득이 어렵다고 하였고, Kim (1996)은 2-3세에 출현하여 완전 습득연령은 6-7세라고 하였다. 좀 더 구체적 으로 Kim과 Pae (2005)는 / 시는 3세 후반, / 씨는 4세 후반에 출현 하여, 5 세 전반 $75 \%$ 의 습득기준에 도달하고 완전 습득연령은 5 세 후반이라고 하였다. 이와 유사하게 $\mathrm{Ha}, \mathrm{Kim}$ 과 $\mathrm{Pi}$ (2019)도 4세 후 반 50\% 이상, 5 세 전반 75\% 이상, 5 세 후반 완전 습득이 가능하다 고 보고하였다. 유음은 초성의 탄설음보다 종성의 설측음이 먼저 발달하는 것으로 알려져 있다(Kim, 1996). 탄설음 /리의 습득 연 령에 대해 Oum (1986)은 5세를 언급하였고, Kim과 Pae (2005)는 3 세 전반 $75 \%$ 의 습득기준에 도달하여 완전 습득연령은 5 세 후반이 라고 하였다. 이와 유사하게 $\mathrm{Ha}, \mathrm{Kim}$ 과 $\mathrm{Pi}$ (2019)도 3세 후반 50\%,
5 세 전반에 $75 \%, 5$ 세 후반에 완전습득을 보고하였다. 이처럼 습득 연령에 대해서는 연구자들마다 다소 차이가 있지만, 분명한 것은 파찰음, 마찰음, 유음의 습득은 다른 말소리들에 비해 늦게, 그리고 점차적으로 이루어진다는 것이다.

오류 측면의 발달과정을 살펴보면, 영어권의 파찰음은 2-3세에 생략이 많고 유성음 $/ \mathrm{b} /$ 보다 무성음 $/ \mathrm{t} /$ 에서 탈경구개음화(depalatalizaton)와 탈파찰음화(deaffrication)가 빈번하여 치음화(dentalization), 후치경음화(postalveolar) 및 설측음화(lateralization) 등 이 나타날 수 있다(Smit, 1993). 한국어의 경우 발달 초기에는 파열 음으로의 대치가 빈번한데, 이러한 오류는 연령이 증가할수록 감소 하지만 5세 후반까지도 지속될 수 있다고 보고되었다(Oum, 1994). 2 세 후반 집단에서 탈파찰음화, 4 세 후반과 5 세 후반 집단에서 치 간음화 오류가 보고되기도 하였다(Kim, 2006). 영어권의 마찰음은 2-3세에 파열음화가 많고, 치간음화는 연령이 증가할수록 감소하 나 9 세의 $10 \%$ 에서 여전히 관찰되었고, 소수 아동에게서는 설측음 화와 후치경음화가 나타나기도 하였다(Smit, 1993). 한국어의 경우 Oum (1994)은 / ㅅ/는 성문마찰음으로 시작하여, 파열음화, 치간음 화 오류를 보이며 습득된다고 보고하였다. 반면 Cheon과 Lee (1999) 는 생략에서 시작하여 대치, 구개음화, 치간음화 오류 순으로 마찰 음을 습득한다고 하였다. 또한 $\operatorname{Kim}$ (2006)은 치간음화는 4세 전반 에서 5 세 전반에 가장 빈번하지만 2 세 후반부터 6 세 전반에 이르기 까지 모든 연령집단의 $15 \%-43 \%$ 아동에서 나타난다고 하면서, 소 수이지만 6세에는 설측음화를 보이기도 한다고 덧붙였다. 유음의 오류 발달과정을 살펴보면, 영어권의 초성 $/ \mathrm{r} /$ 는 2 세에 생략과 활음 화가 많고 6 세까지 / $/ /$ 로의 대치가 지속되는 반면, 종성 /1/은 2세에 생략 및 $/ \mathrm{w} /$, 원순모음, 중성모음(schwa)으로의 대치가 많고 드물지 만 치간음화, 양순음화, 연구개음화도 관찰되었다(Smit, 1993). 한 국어의 경우, 2 세 후반부터 5 세 후반까지 유음의 생략 및 활음화가 나타났고, 유음의 비음화와 파열음화는 연령이 증가하면서 감소되 지만 6세 전반까지도 소거되지 않을 수 있다(Kim, 2006). 초성 /리 는 발달과정에서 주로 생략이 많고, 활음화, 비음화, 파열음화로 대 치되며, 종성 /리는 주로 활음화가 많고 생략, 비음화, 파열음화로 대치된다는 보고도 있다(Choi \& Kim, 2013). Smit (1993)이 언급한 것처럼 말소리 오류의 발달과정은 말소리의 종류에 따라 그리고 연 령에 따라 매우 상이함을 알 수 있다. 그러나 이들에 대해 한 가지 공통점은 그 발달의 여정이 결코 짧지 않다는 것이다.

조음적 난이도가 높아 그것을 확실하게 습득하기까지의 여정이 긴 만큼, 목표음의 전형에서 약간씩 벗어난 채 목표 말소리에 점차 적으로 접근해가는 과정이 동반될 것이다. 그로 인해 해당 음소의 경계 내에 있으나 정확하지는 않는 소리, 즉 왜곡 오류가 많이 산출 
될 가능성이 있다. 왜곡은 음운 단계의 문제라기보다 그 이후 운동 실행의 부정확함, 미성숙 등을 반영하는 오류이다(Dodd, TtofariEecen, Brommeyer, Reilly, \& Morgan, 2018). 앞에서 살펴보았던 치 경마찰음의 치간음화, 탄설음의 설측음화 등은 대표적인 왜곡 오 류로, 이는 해당 말소리의 음운적 표상이 온전하게 존재함에도 불 구하고 그것의 조음운동적 실행에 대한 어려움 또는 잘못된 습관 등에 의해 초래될 수 있다. 오류 말소리를 효율적으로 가르치기 위 해서는 해당 말소리에 대한 조음운동의 변화과정을 상세히 파악하 고 있어야 할 것이며, 이 과정을 모두 거친 후에야 비로소 만족할 만 한 전형적 목표음의 산출이 가능할지도 모르겠다. 그럼에도 불구 하고, 말소리 오류에 대한 연구는 제법 많으나, 왜곡 오류까지 포함 하여 분석한 연구는 드물다. Cheon과 Lee (1999), Choi와 Kim (2013) 등이 왜곡을 포함한 연구를 진행한 바 있으나, 대상 아동의 연령이 제한적이거나 특정 말소리만 다루고 있어 여러 연령대에 걸쳐 다양 한 말소리의 왜곡 발달을 모두 살펴보지는 못 하였다. 적어도 복잡 한 조음운동기술을 요하는 파찰음, 마찰음, 유음에 한해서는 오류 의 변화과정을 왜곡 중심으로 상세히 살펴볼 필요가 있다.

따라서 본 연구에서는 파찰음, 마찰음, 유음 산출 시 나타나는 오류를 왜곡에 초점을 두어 분석한 후, 2 세 후반부터 7세에 이르는 말소리 발달의 전 시기 동안 연령에 따른 왜곡 산출의 변화과정을 살펴보고자 하였다. 이를 위해 각 말소리에서 연령에 따른 오류율 의 변화를 먼저 살펴본 후, 연령 증가와함께 나타나는 왜곡 오류패 턴의 변화를 알아보았다. 보다 상세한 정보를 얻기 위해, 파찰음, 마 찰음, 유음의 각 말소리들(/ㅈ/, /ㅊ/, / ㅉ/, / / /, / ㅆ/, /ㄹ/)에 대해 개 별적인 분석을 실시하였고, 또한 위치에 따라 운동 방법이 다소 상 이하고 발달 양상에도 차이가 있는 초성 위치의 탄설음과 종성 위 치의 설측음을 분리하여 분석하였다. 연령 별로 가장 선호하는 왜 곡 오류패턴이 무엇인지, 어떤 양상으로 왜곡 오류패턴이 분포되는 지 등에 대한 정보는 파열음, 마찰음, 유음을 정확하게 산출하기 위 해 어떠한 조음운동능력이 필요하며, 혹은 거꾸로 어떠한 조음운 동기술이 어려운지에 대해 의미 있는 정보를 제공할 것이다.

\section{연구방법}

\section{연구대상}

본 연구의 대상자는 우리말조음음운검사2 (UTAP2; Kim et al., 2020)의 규준작업을 위해 모집한 2 세 후반부터 7세까지의 아동이 다. 어린이집, 유치원, 학교, 지역사회복지센터, 지인의 가정 등 기관 과 장소를 제한하지 않았으나 언어치료실, 특수기관, 재활기관 등 장애 아동들을 대상으로 하는 기관은 제외하였다. 모든 대상자에
Table 1. Participants' characteristics

\begin{tabular}{lcc}
\hline & Number of subjects (\%) & REVT-R (raw score) $)^{\mathrm{a}}$ \\
\hline $\begin{array}{l}\text { Gender } \\
\text { Male }\end{array}$ & $267(48)$ & \\
Female & $289(52)$ & \\
Age (yr;mo) & & \\
$2 ; 6-2 ; 11$ & $59(10.6)$ & $21.02(9.71)$ \\
$3 ; 0-3 ; 5$ & $54(9.7)$ & $28.19(10.91)$ \\
$3 ; 6-3 ; 11$ & $57(10.3)$ & $32.88(10.93)$ \\
$4 ; 0-4 ; 5$ & $65(11.7)$ & $45.95(12.11)$ \\
$4 ; 6-4 ; 11$ & $70(12.6)$ & $49.00(11.39)$ \\
$5 ; 0-5 ; 5$ & $50(9.0)$ & $57.86(12.23)$ \\
$5 ; 6-5 ; 11$ & $73(13.1)$ & $64.49(8.94)$ \\
$6 ; 0-6 ; 11$ & $82(14.7)$ & $72.44(10.59)$ \\
$7 ; 0-7 ; 11$ & $46(8.3)$ & $87.07(12.41)$ \\
Total & $556(100)$ & $51.44(22.49)$ \\
\hline
\end{tabular}

Values are presented as mean (SD).

${ }^{\text {aREVT-R }}=$ Receptive \& Expressive Vocabulary Test-Receptive vocabulary (Kim, Hong, Kim, Jang, \& Lee, 2009).

게 사전 검사로 수용 - 표현어휘력검사(REVT; Kim, Hong, Kim, Jang, \& Lee, 2009)를 실시하여 수용어휘력이 해당 연령대에서 -2 $\mathrm{SD}$ 미만인 아동은 연구대상에서 제외하였다. 대상자는 2 세 6 개월 부터 7세 11 개월에 해당하는 556명의 아동이며, 2세 6개월부터 5세 까지는 6 개월 단위로, 6 세와 7세는 1년 단위로 연령집단을 구분하였 다. 연령집단 별 대상자 수와 REVT-R 점수는 Table 1과 같다. 연령 집단에 따른 성별분포에는 유의한차이가 없었다 $\left(\chi^{2}=4.040, p>.05\right)$.

\section{연구도구 및 실험방법}

본 연구의 실험과제로 UTAP2의 단어수준 검사를 이용하였다. 실험은 아동이 다니고 있는 어린이집, 유치원 또는 거주하는 가정 에서 소음이 적은 독립적인 장소를 택하여 일대일로 이루어졌다. 모든 대상자에게 사전 검사인 수용-표현어휘력검사(REVT-R)와 본 검사인 UTAP2의 단어수준 검사를 실시하였다. 검사자는 아동 의 반응을 기록지에 바로 전사하였고 모든 검사 과정을 비디오 또 는 오디오로 녹화, 녹음하였다.

\section{자료처리}

전국 규모의 대규모 규준자료를 수집하기 위해 서울, 경기도, 충 청도, 경상도, 전라도 및 제주도 지역에서 다수의 연구원들이 검사 자로 참여하였기 때문에, 본 연구의 제 1 저자가 녹화 또는 녹음된 자 료를 반복 재생하여 다시 음성전사하고 검사 당시 현장에서 직접 전사하였던 원자료와 대조하는 과정을 일일이 거쳤다. 본 연구에서 는 UTAP2의 전체 30 개 단어 가운데 파찰음, 마찰음(성문마찰음 
제외), 유음이 포함된 단어 21 개만을 분석하였다. 21 개 단어에서 나 타날 수 있는 각 목표 말소리의 산출 기회 수는 / ㅈ/ 5 회, /ㅊ/ 4회, /ㅉ/ / 회, / ㅅ/ 3회, / ㅆ/3회였고, 유음/ㄹ/는 탄설음 6회, 설측음 2 회 였다. 우선 연령 증가에 따른 각 말소리 별 오류의 감소 추세를 파악 하기 위해, 7 개 말소리에 대한 연령집단 별 평균 오류율을 비교하였 다. 오류율은 왜곡을 포함하여 오조음한 경우에 1점씩을 부여하여 각 산출 기회에 대한 백분율로 산출하였다.

그러고 나서 오류패턴 분석을 위해 대상자들이 본 실험과제에서 보인 왜곡 오류를 오류패턴으로 분류하여 범주화하는 작업을 실 시하였다. 그 결과 경구개음 중 / ㅈ/와 / ㅉ/는 파열음화(stopping), 설측음화(lateralization) 및 약화(weakening)로, /ㅊ/는 파열음화 와 약화로, 그리고 마찰음(/ㅅ/, / 씨)은 치간음화(dentalization, interdentalization), 경구개음화(palatalization), 설측음화 및 약화로 분류할 수 있었다. 유음의 경우 통상적으로 대치 오류로 범주화되 는 활음화(gliding)를 왜곡 오류에 포함시킬지에 대해 고민의 여지 가 있었다. 활음은 한국어에 엄연히 음소로 존재하기 때문에 유음 이 활음으로 오조음되는 경우 원칙적으로는 대치 오류에 해당한 다. 그러나 이것이 두 말소리 간 음소적 경계의 불명확함으로 인해 초래된 것인지, 아니면 운동실행이 약화되어 그 결과가 나타난 것 인지에 대해, 저자들의 임상적 경험, 유음 산출 시 힘 조절에 일시적 으로 실패하면 약화된 발음인 활음으로 산출될 수 있다는 음성학 분야의 이론(Howell, 1991) 등에 근거하여 후자의 가능성이 높다 고 판단하였다. 활음으로의 오류가 유음에 대한 운동방법적 어려 움을 시사한다고 판단한 이상, 유음의 활음화를 왜곡 오류의 연장 선으로 간주하는 것이 타당할 것이다. 따라서 유음의 오류패턴은 활음화까지 포함하여, 탄설음/리는 설측음화, 약화 및 활음화로, 설측음/르는 활음화와약화로 분류할 수 있었다.

본 연구는 왜곡 오류의 발달 양상에 초점을 두고 있으나, 서론에 서도 언급하였듯이, 왜곡 오류만을 독립적으로 분석할 경우 대상 아동의 오류를 양적으로 과소 평가하거나 질적으로 단순화하여 파악할 가능성이 있다. 따라서 전체 오류의 틀 안에서 각 왜곡 오류 패턴이 차지하는 비율을 제시해주는 것이 바람직할 것이다. 이러한 이유로 본 연구에서는 대치 및 생략 오류와 함께 각 왜곡 오류패턴 별 비율에 대한 분포를 비교하였다. 본 연구에서 분석한 오류패턴 을 정리하면 다음과 같다. 대치는 목표음을 우리말의 다른 음소로 바꾸어 잘못 발음한 경우이다. 이 때 유음을 활음으로 오조음한 경 우는 제외하였다. 본 연구의 초점이 왜곡 오류인 만큼 대치 오류 내 에서 구체적인 오류패턴은 분석하지 않았다. 생략은 목표음을 생 략하여 해당 위치에 아무 음소도 존재하지 않는 경우이다.

파찰음의 파열음화는 경구개 위치에서 조음방법을 파열음으로
산출한 경우, 설측음화는 개방 시 혀의 측면 통로로 기류를 서서히 방출한 경우, 약화는 폐쇄가 불확실하여 마치 생략처럼 들리기도 하지만 혀의 상승으로 인한 구강 중앙부의 방해 자체는 지각할 수 있는 경우이다. 마찰음의 치간음화는 조음위치가 전방화되어 치음 또는 치간에서 산출한 경우, 경구개음화는 조음위치가 후방화되어 경구개에서 산출한 경우, 약화는 치경 위치에서 마찰성 소음이 약 하여 마치 생략과 성문마찰음 / ㅎ/의 중간 소리처럼 지각되는 경우 이다. 유음의 활음화는 유음 대신 활음 / j/로 지각되는 경우, 설측음 화는 탄설음 산출 시 혀 중앙의 치경 접촉기간이 다소 길어져 설측 음처럼 지각되는 경우, 약화는 혀가 치경에 확실히 닿지 않은 경우, 또는 약간 후방화된 채 여전히 혀가 입천장에 확실히 닿지 않아 권 설음(retroflex)처럼 들리는 경우, 그리고 폐쇄의 지속시간이 다소 길어졌으나/디보다는 약한 소리로 지각되는 경우를 모두 포함한 다. 이와 같은 파찰음, 마찰음, 유음의 왜곡 오류패턴을 Appendix 1 에 정리하였다.

목표 말소리를 모두 정조음한 아동은 오류패턴 분석 대상에서 제외하였다. 동일한 말소리 유형(예: 파찰음)에 대해 동일한 오류패 턴(예: 파열음화)을 최소 2 회 이상 보인 경우만 오류패턴으로 인정 하였으나, 실제 분석은 각 말소리(예: / ㅈ/, / / /, / ㅉ/)에 대해 개별적 으로 이루어졌다. 대상자마다 전체 오류패턴 수가 다르기 때문에, 각 대상자 별로 전체 오류패턴에 대한 각 오류패턴 별 비율을 백분 율로 산출하여 구하였다.

\section{신뢰도}

오류패턴 분석에 대한 신뢰도를 검증하기 위해 평가자 간 신뢰도 를 실시하였다. 제 1 평가자는 제 1 저자로 1 급 언어재활사 자격증을 소지한 임상경력 12 년 이상의 치료사였고, 제 2 평가자는 제 2 저자로 1 급 언어재활사 자격증을 소지한 임상경력 8년 이상의 치료사였다. 약 6 개월 간 연습과 논의과정을 거쳐 대상 아동 중 15 명에 대한 두 평가자 간 일치도가 $95 \%$ 이상인 것을 확인한 후, 전체 대상자의 $20 \%$ 에 해당하는 110 명의 자료를 무작위로 추출하여 신뢰도 평가 를 실시하였다. 신뢰도는 두 평가자 간 일치하는 항목 수(2,043개) 를 전체 항목 수(2,530개)로 나눈 후 100 을 곱하여 산출하였다. 그 결과 오류패턴에 대한 두 평가자 간 일치도는 $80.75 \%$ 이었다.

\section{통계분석}

자료의 통계처리는 SPSS ver 24.0 (IBM, Armonk, NY, USA)을 이용하여 분석하였다. 첫째, 파찰음, 마찰음, 유음 산출 시 연령집 단 간 오류율에 유의한 차이가 있는지 알아보기 위해, 각 말소리 별 로 일원분산분석(one way ANOVA)을 실시하였다. 둘째, 파찰음, 
마찰음, 유음 산출 시 연령집단 간 오류패턴별 비율에 유의한 차이 가 있는지 알아보기 위해, 각 말소리 별로 1피험자 간-1피험자 내 혼 합설계에 따른 반복측정분산분석(repeated measures ANOVA)을 실시하였다. 이때 구형성 가정이 충족되지 않을 경우 GreenhouseGeisser의 수정된 자유도를 이용하여 결과를 해석하였다. 피험자 간 사후검정은 Scheffé 검정을, 피험자 내 주효과 검정은 Bonferro$\mathrm{ni}$ 검정을 실시하였고, 이요인 상호작용효과는 COMPARE 하위명 령어를 입력한 syntax를 실행시켜 사후검정을 실시하였다.

\section{연구결과}

\section{파찰음, 마찰음, 유음 산출에 대한 연령집단 간 오류율 비교}

파찰음, 마찰음, 유음 산출에 대한 연령집단별 평균 오류율 및 표 준편차는 Appendix 2에 제시하였다. 각 말소리에서 연령집단 별 오 류율에 대해 일원분산분석 결과 / ㅈ/ $\left(F_{(8,547)}=31.999\right), /$ ㅊ/ $\left(F_{(8,547)}=\right.$ $25.594), /$ 不 $/\left(F_{(8,547)}=26.590\right), /$ 人 / $\left(F_{(8,547)}=24.691\right), /$ 从 / $\left(F_{(8,547)}=\right.$ $31.993)$, 탄설음 /리 $\left(F_{(8,547)}=57.711\right)$, 설측음 /ㄹ/ $\left(F_{(8,547)}=39.193\right)$ 모두에서 연령집단 간 오류율에 유의한 차이가 있었다 $(p<.001)$ (Figure 1).

사후검정 결과, / 지의 경우 2 세 후반은 4 세 전반 이후와, 3 세 전 반은 3 세 후반 이후와, 3 세 후반과 4 세 전반은 5 세 전반 및 6 세 이후 와 유의한 차이가 있었으나 $(p<.05), 4$ 세 후반부터는 이후 연령집 단들과 유의한 차이가 없었다. /ㅊ/의 경우 2 세 후반은 4 세 전반 이 후와, 3 세 전반은 3 세 후반 이후와, 3 세 후반과 4 세 전반은 6 세 이후 와 유의한 차이가 있었으나 $(p<.05), 4$ 세 후반부터는 이후 연령집
단들과 유의한 차이가 없었다. /ㅉ/의 경우 2 세 후반은 4 세 전반 이 후와, 3 세 전반은 3 세 후반 및 4 세 후반 이후와 유의한 차이가 있었 으나 $(p<.05), 3$ 세 후반은 이후 집단들과 유의한 차이가 없었다. 그 러나 4세 전반에서 다시 5 세 전반, 6 세 및 7세와 유의한 차이가 나 타났고 4 세 후반에서도 7 세와 유의한 차이를 보이다가 $(p<.05), 5$ 세 전반부터는 이후 연령집단들과 유의한 차이가 없었다.

/시의 경우 2 세 후반은 4 세 전반 이후와, 3 세 전반은 4 세 후반 이 후와, 3 세 후반은 5 세 전반 이후와, 4 세 전반과 후반은 6 세와 7세와 유의한 차이가 있었고 $(p<.05), 5$ 세 전반부터는 이후 연령집단들과 유의한 차이가 없었다. / 씨의 경우 2세 후반은 3세 후반 이후와, 3 세 전반은 4 세 전반 이후와, 3 세 후반과 4 세 전반은 5 세 전반 이후 와, 4 세 후반은 5 세 후반 이후와 유의한 차이가 있었고( $p<.05), 5$ 세 전반부터는 이후 연령집단들과 유의한 차이가 없었다.

탄설음/리의 경우 2 세 후반은 3 세 전반 이후와, 3 세 전반은 3 세 후반 이후와, 3 세 후반은 5 세 전반 이후와, 4 세 전반과 후반은 5 세 전반 이후와 유의한 차이가 있었으나 $(p<.05), 5$ 세 전반부터는 이 후 연령 집단과 유의한 차이가 없었다. 설측음/리의 경우 2 세 후반 은 3 세 전반 이후와, 3 세 전반은 4 세 전반 이후와, 3 세 후반은 5 세 후반 이후 집단과 유의한 차이가 있었으나 $(p<.05), 4$ 세 전반부터 는 이후 연령집단들과 유의한차이가 없었다.

\section{파찰음, 마찰음, 유음 산출에 대한 연령집단 간 오류패턴 별 비율 비교}

발생하지 않은 오류패턴은 각 말소리에 대한 결과에서 제외하였

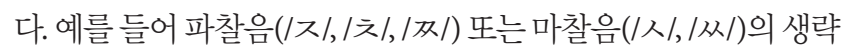

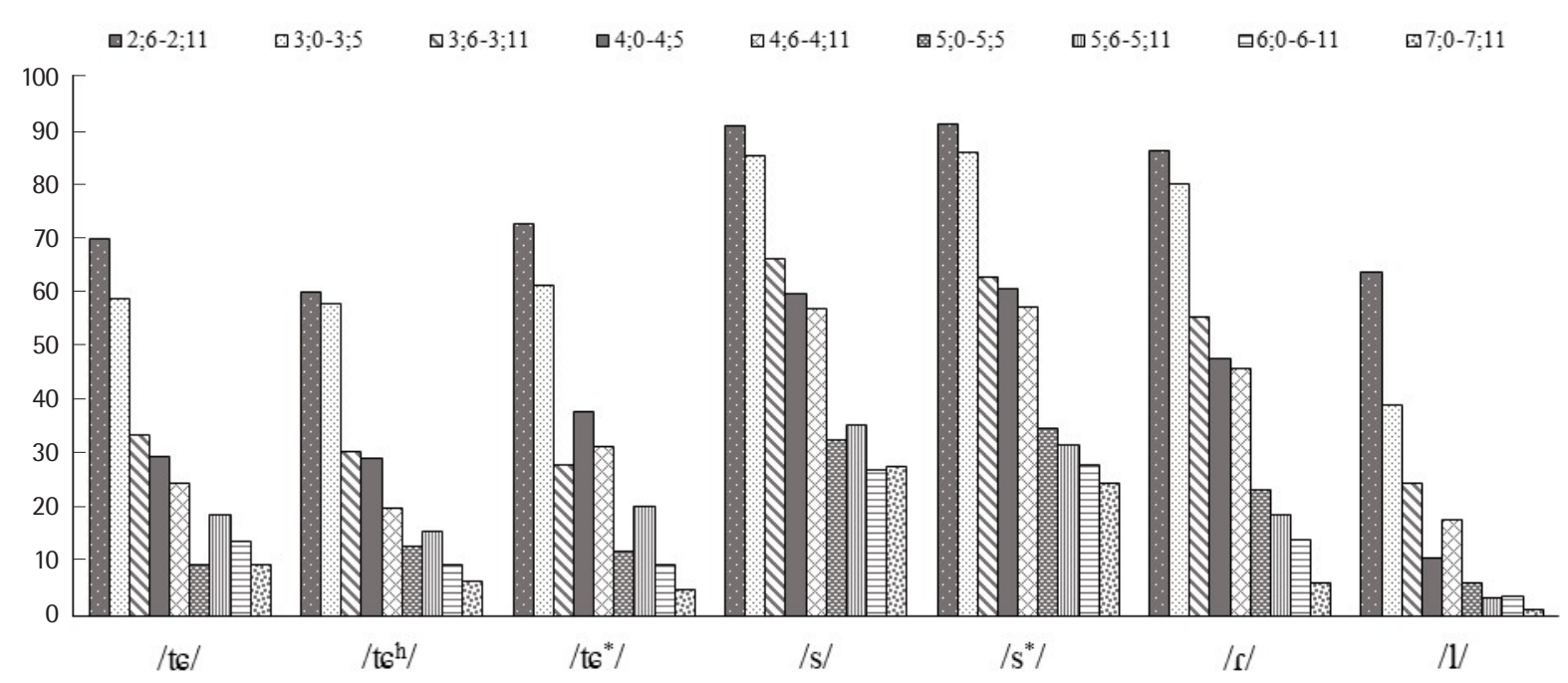

Figure 1. The error rates of affricates, fricatives, and liquids by age groups. 
은 어떤 연령집단에서도 관찰되지 않았다. 따라서 파찰음과 마찰 음 분석 시 생략은 오류패턴에 포함하지 않았고 나머지 오류패턴 들에 대해서만 그 분포를 비율로 기술하였다.

\section{파찰음 산출에 대한 연령집단 간 오류패턴별 비율 비교}

/ㅈ/에 대한 연령집단간 오류패턴별 비율 비교

/ㅈ/ 산출 시 나타난 각 연령집단의 오류패턴별 비율에 대한 기 술통계는 Appendix 3과 같다. 반복측정분산분석 결과, 오류패턴 에 대한 주효과가 유의하였고 $\left(F_{(1.102,325.083)}=219.087, p<.001\right)$, 오류 패턴과 연령 간 상호작용효과가 유의하였다 $\left(F_{(8.816,325.083)}=12.237\right.$, $p<.001)$. 오류패턴의 주효과에 대한 사후검정 결과, 파열음화가 대 치, 설측음화 및 약화보다, 대치가 설측음화와 약화보다 유의하게 많았으나 $(p<.001)$, 설측음화와 약화의 차이는 유의하지 않았다. 오류패턴과 연령집단 간 상호작용효과에 대한 사후검정 결과, 2 세 후반과 3세 전반에는 대치가 나머지 오류패턴들보다, 파열음화가 설측음화와 약화보다 유의하게 많았다 $(p<.001) .3$ 세 후반에 들어 5 세 전반까지 대치와 파열음화 간 유의한 차이가 없어진 채, 두 오 류패턴은 여전히 설측음화와 약화보다 유의하게 많았다 $(p<.001)$. 이후 5세 후반부터 6세까지 파열음화가 대치를 포함한 나머지 오류 패턴들보다, 대치가 설측음화와 약화보다 유의하게 많다가 $(p<.05)$, 7세에는 파열음화만 나머지 오류패턴들보다 유의하게 많았다 $(p<.05)$ (Figure 2).
/ㅊ/에 대한 연령집단간 오류패턴별 비율 비교

/ㅊ/ 산출 시 나타난 각 연령집단의 오류패턴별 비율에 대한 기 술통계는 Appendix 3과 같다. 반복측정분산분석 결과, 오류패턴 에 대한 주효과가 유의하였고 $\left(F_{(1.108,244.271)}=101.939, p<.001\right)$, 오류 패턴과 연령집단 간 상호작용효과가 유의하였다 $\left(F_{(8.142,244.271)}=\right.$ $6.667, p<.001)$. 오류패턴에 대한 사후검정 결과, 파열음화가 대치 와 설측음화보다, 대치가 설측음화보다 유의하게 많이 나타났다 ( $p<.001)$. 오류패턴과 연령 간 상호작용효과에 대한 사후검정 결 과, 2 세 후반은 대치, 파열음화, 설측음화 순으로 유의하게 많았고 $(p<.01), 3$ 세 전반에서 5 세 전반까지는 대치와 파열음화 간 유의한 차이가 없어진 채 두 오류패턴이 설측음화보다 유의하게 많았다 $(p<.001)$. 그러다가 5세 후반 이후부터 파열음화가 대치와 설측음 화보다 유의하게 많아졌다 $(p<.001)$ (Figure 3$)$.

/ㅉ/에 대한 연령집단간 오류패턴별 비율 비교

/찌 산출 시 나타난 각 연령집단의 오류패턴별 비율에 대한 기 술통계는 Appendix 3과 같다. 소수의 아동만 오류를 보인 7세 집단 은/ㅉ/ 분석에서 제외하였다. 반복측정분산분석 결과, 오류패턴에 대한주효과가 유의하였고 $\left(F_{(1.093,252.453)}=126.573, p<.001\right)$, 오류패턴 과 연령 간 상호작용효과 유의하였다 $\left(F_{(8.743,252.453)}=6.683, p<.001\right)$. 오류패턴의 주효과에 대한 사후검정 결과, 파열음화가 나머지 오류 보다, 대치가 설측음화와 약화보다 유의하게 많았으나 $(p<.001)$, 설
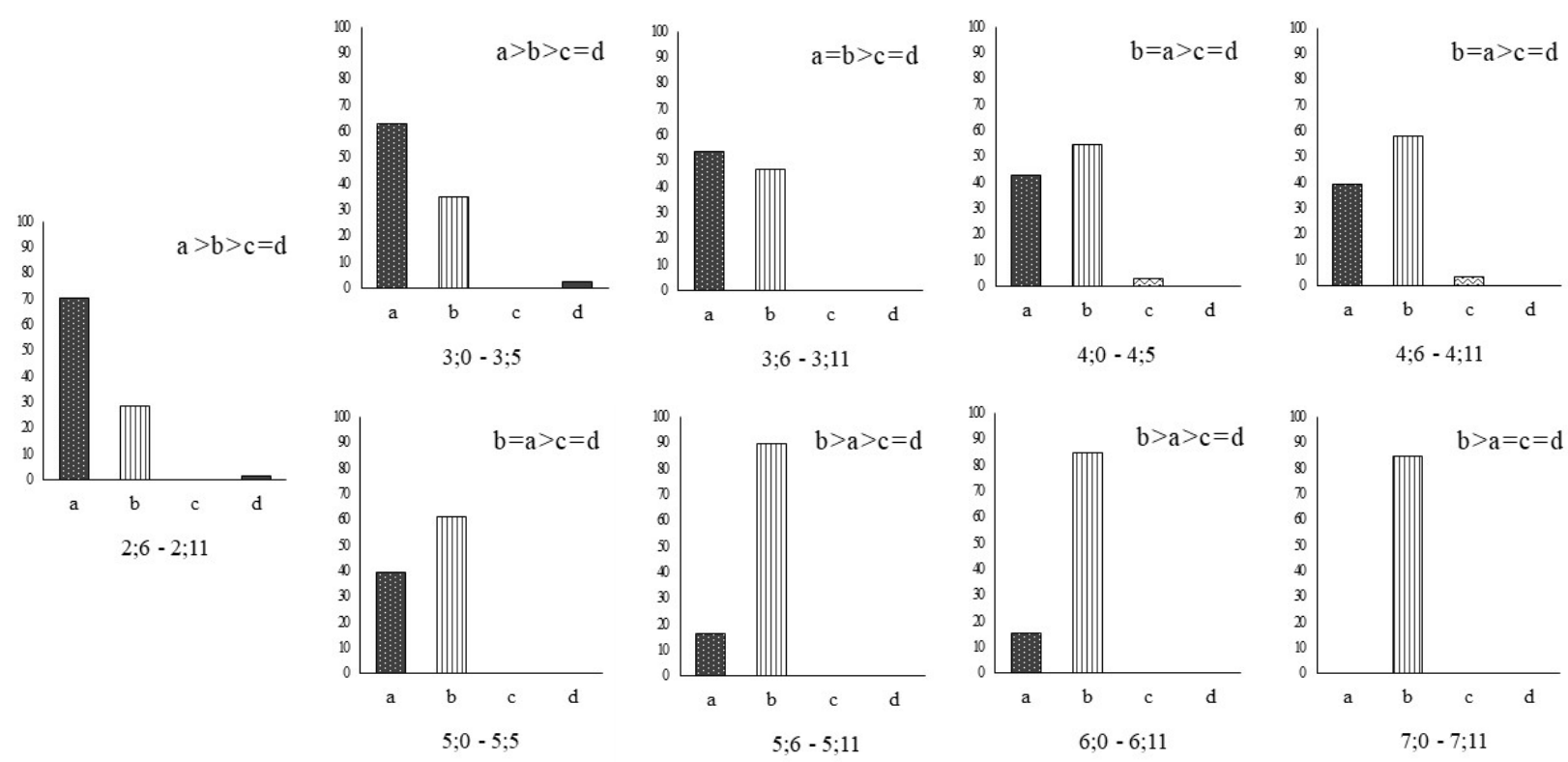

Figure 2. The rates of error patterns in /t $/$ / by age groups. $a=$ substitution; $b=$ stopping; $c=$ lateralization; $d=$ weakening. 

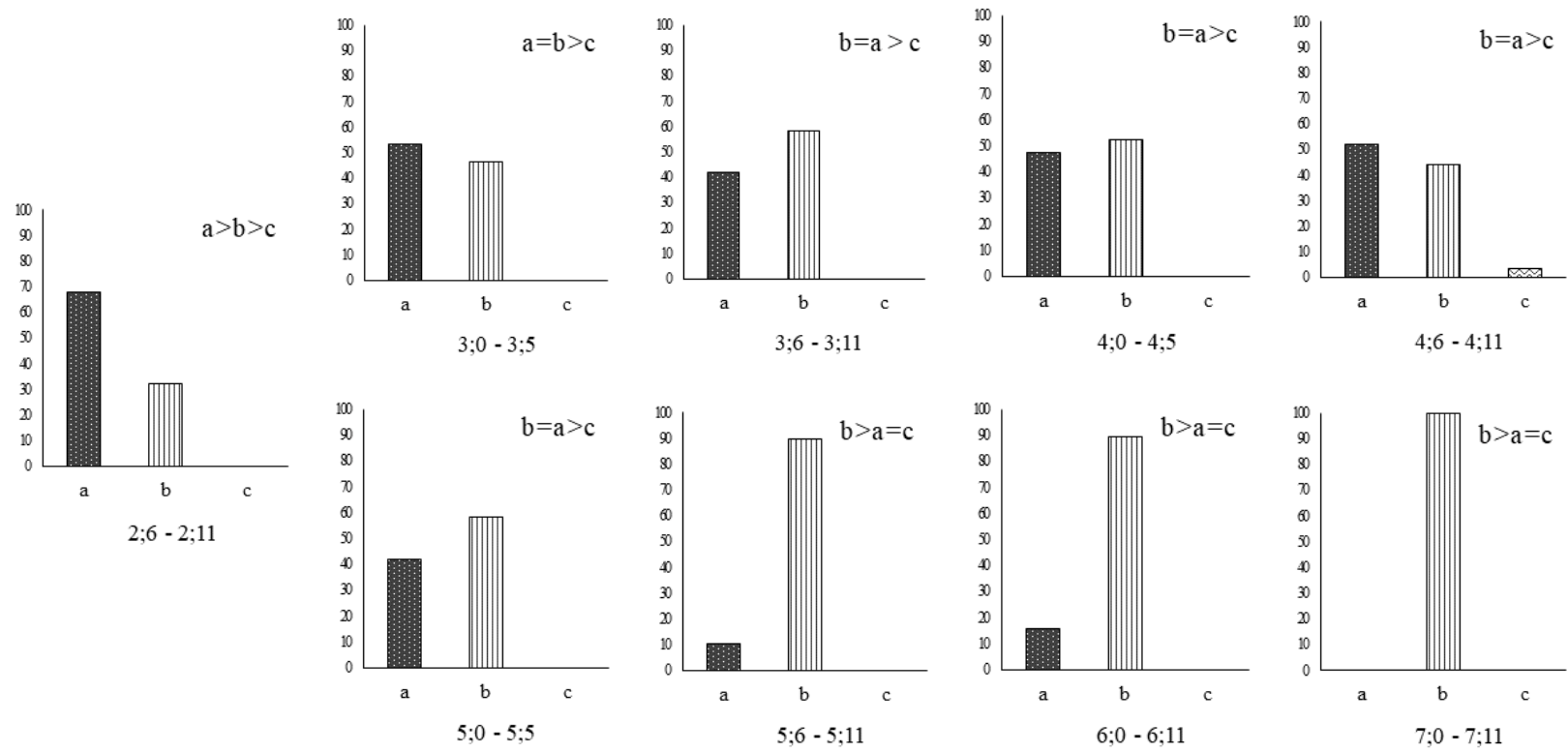

Figure 3. The rates of error patterns in $/ \mathrm{tc}^{\mathrm{h}} /$ by age groups. $a=$ substitution; $b=$ stopping; $c=$ lateralization.
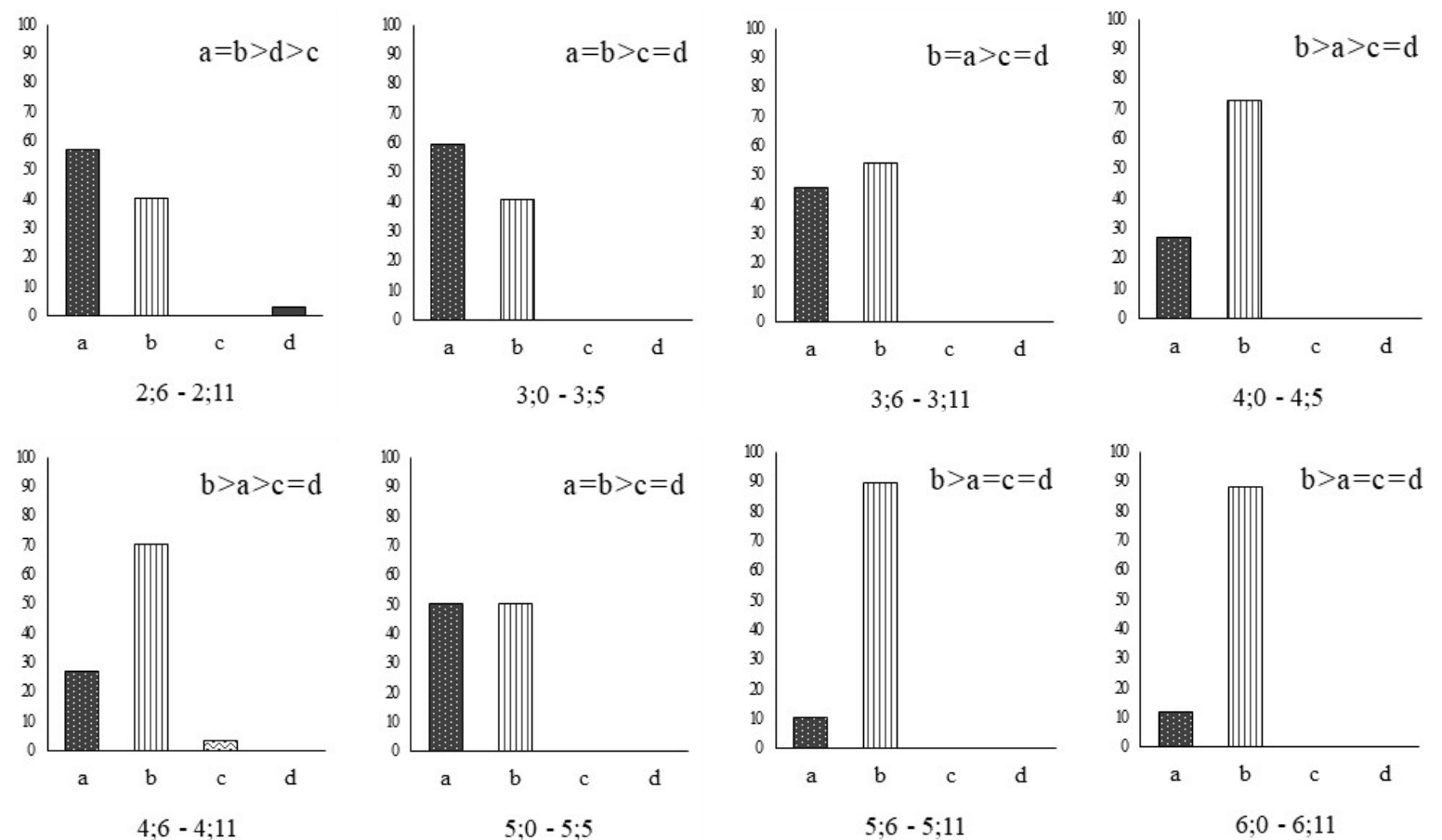

Figure 4. The rates of error patterns in $/ \mathrm{tc}^{*} /$ by age groups.

$\mathrm{a}=$ substitution; $\mathrm{b}=$ stopping; $\mathrm{c}=$ lateralization; $\mathrm{d}=$ = weakening .

측음화와 약화 간 차이는 유의하지 않았다 $(p>.05)$. 오류패턴과 연 령집단 간 상호작용효과에 대한 사후검정 결과, 2 세 후반에서는 대 치와 파열음화가 설측음화와 약화보다 $(p<.001)$, 약화가 설측음화 보다 유의하게 많았다 $(p<.05)$. 3 세 전반과 후반도 2 세 후반과 유사

하였지만 약화와 설측음화의 차이가 유의하지 않았다. 그러다가 4 세 전반과 후반에 파열음화가 대치를 포함한 나머지 오류패턴들보 다 유의하게 많아졌고 $(p<.001), 5$ 세 전반에는 다시 파열음화와 대 치 간 유의한 차이가 없어진 채 두 오류패턴이 설측음화와 약화보 
다 유의하게 많았다 $(p<.001)$. 이후 5 세 후반과 6 세에 또 다시 파열 음화가 대치를 포함한 나머지 오류패턴들보다 유의하게 많아졌고 ( $p<.001), 7$ 세에는 어떤 방식으로든 오류를 보이는 아동이 거의 없 었다(Figure 4).

마찰음 산출에 대한 연령집단 간 오류패턴별 비율 비교 /시에 대한 연령집단 간 오류패턴별 비율 비교

/시산출시 나타난 각 연령집단의 오류패턴별 비율에 대한 기술 통계는 Appendix 4 와 같다. 반복측정분산분석 결과 오류패턴의 주효과가 유의하였고 $\left(F_{(2.122,755.445)}=132.080, p<.001\right)$, 오류패턴과 연령 간 상호작용효과가 유의하였다 $\left(F_{(16.976,755.445)}=15.794, p<.001\right)$. 오류패턴의 주효과에 대한 사후검정 결과, 치간음화와 대치가 약 화, 구개음화 및 설측음화보다, 약화가 구개음화와 설측음화보다 유의하게 많았으나 $(p<.001)$, 구개음화와 설측음화의 차이는 유의 하지 않았다( $p>.05)$. 오류패턴과 연령집단 간 상호작용효과에 대 한 사후검정 결과, 2 세 후반에서는 대치가 나머지 오류패턴들보다 ( $p<.001)$, 치간음화와 구개음화가 설측음화보다 많이 나타났고 ( $p<.05), 3$ 세 전반도 이와 유사한 양상을 보였다. 3 세 후반에도 여 전히 대치가 나머지 오류패턴들보다 유의하게 많았지만 $(p<.01)$, 치간음화의 비율이 높아져 약화, 구개음화 및 설측음화보다 유의하 게 많아졌다 $(p<.001)$. 이후 4 세 전반과 후반에 들어 대치와 치간음 화 간 유의한 차이가 없어진 채 두 오류패턴이 나머지 오류패턴들 보다 유의하게 많았고 $(p<.001)$, 나머지 오류패턴들 내에서는 대략
약화, 구개음화, 설측음화 순으로 그 차이가 유의하거나 유의하지 않았다. 그러다가 5 세 전반에 치간음화가 대치를 포함한 나머지 오 류패턴들보다 유의하게 많아졌고( $p<.01)$, 대치도 약화, 구개음화, 설측음화보다는 여전히 유의하게 많았다 $(p<.05) .5$ 세 후반에 오면 치간음화만 다른 오류패턴들보다 유의하게 많다가 $(p<.001), 6$ 세 에 들어 약화의 비율이 높아져 치간음화와 약화 간 차이가 없어진 채 두 오류패턴이 나머지 오류패턴들보다 유의하게 많아졌다 $(p<.01)$. 7세에 다시 치간음화가 약화를 포함한 다른 오류패턴들보다 유의 하게 많아졌고 $(p<.05)$, 여전히 약화도 대치, 구개음화 및 설측음화 보다는 유의하게 많았다 $(p<.05)$ (Figure 5$)$.

/씨에 대한 연령집단간 오류패턴별 비율 비교

/씨 산출 시 나타난 각 연령집단의 오류패턴별 비율에 대한 기술 통계는 Appendix 4 와 같다. 반복측정분산분석 결과, 오류패턴의 주효과가 유의하였고 $\left(F_{(1.569,572.510)}=182.087, p<.001\right)$, 오류패턴과 연령 간 상호작용효과도 유의하였다 $\left(F_{(12.548,572.510)}=15.196, p<.001\right)$. 오류패턴의 주효과에 대한 사후검정 결과 치간음화와 대치는 약화 와 구개음화보다, 약화는 구개음화보다, 대치는 설측음화보다 유의 하게 많았지만 $(p<.001)$, 치간음화와 대치 간 차이는 유의하지 않 았다 $(p>.05)$. 오류패턴과 연령집단 간 상호작용효과에 대한 사후 검정 결과, 2 세 후반에는 대치가 다른 오류패턴들보다 유의하게 많 았고 $(p<.001), 3$ 세 전반부터 3 세 후반까지는 대치가 다른 오류패턴 들보다 $(p<.001)$ 치간음화가 구개음화, 설측음화, 약화보다 유의하
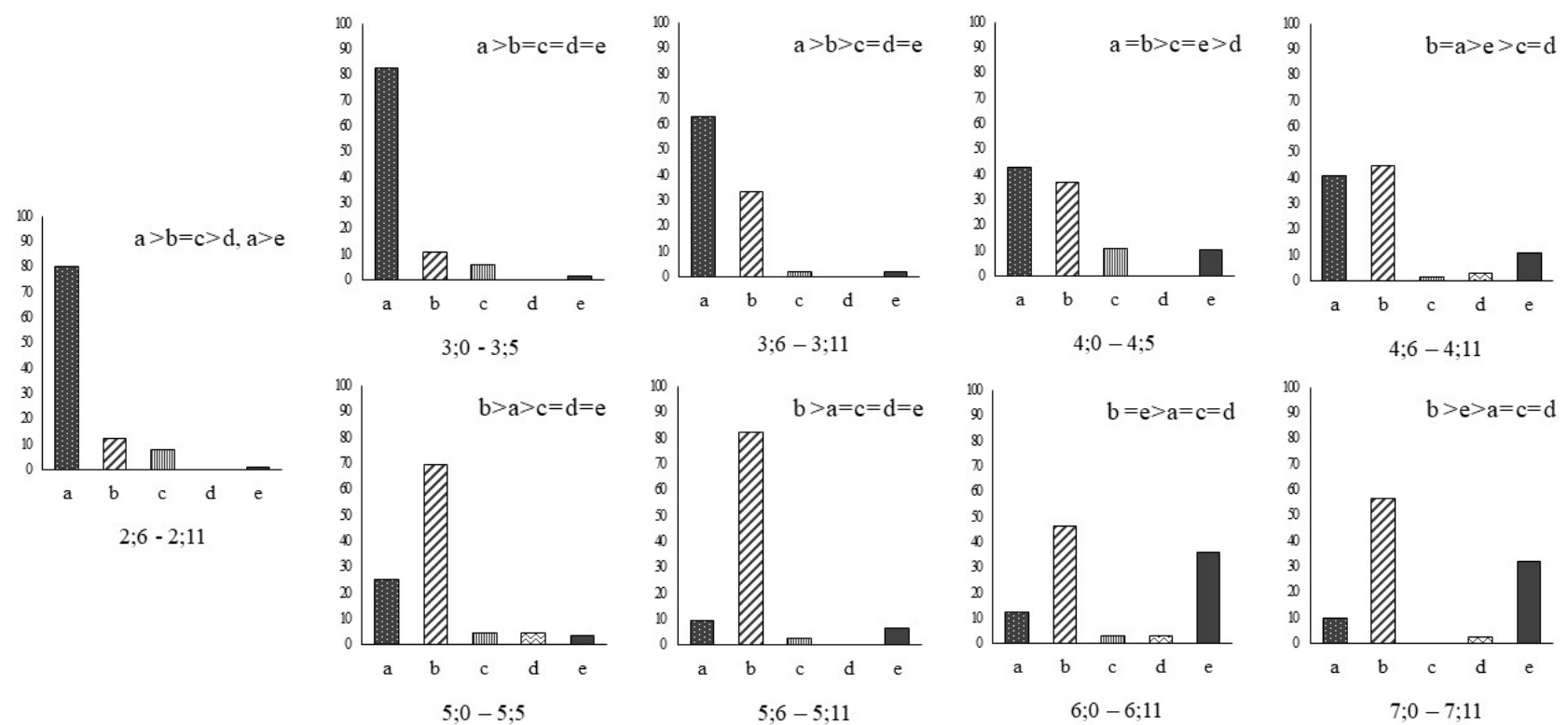

Figure 5. The rates of error patterns in /s/ by age groups.

$a=$ substitution; $b=$ dentalization/interdentalization; $c=$ palatalization; $d=$ lateralization; $e=$ weakening. 
게 많았다 $(p<.05) .4$ 세 전반과 후반에서는 대치와 치간음화 간 차 이가 없어진 채 두 오류패턴이 나머지 오류패턴들보다 유의하게 많 았고 $(p<.001)$, 나머지 오류패턴들 간에는 근소하게 그 차이가 유 의하거나 유의하지 않았다. 5 세 전반에 들어 치간음화가 대치를 포 함한 나머지 오류패턴들보다 유의하게 많아졌고 $(p<.05)$, 대치도 구개음화, 설측음화, 약화보다는 유의하게 많았다 $(p<.001)$. 그러다 가 5 세 후반에 들어 치간음화만 다른 오류패턴들보다 유의하게 많 게 되었다 $(p<.001) .6$ 세와 7세에도 치간음화가 다른 오류패턴들보 다 유의하게 많았지만, 나머지 오류패턴들 내에서는 6세의 경우 대 치를, 7세의 경우 약화와 설측음화를 보다 선호하는 경향을 보였다 $(p<.05)$ (Figure 6).

\section{유음 산출에 대한 연령집단 간 오류패턴별 비율 비교} 탄설음/리에 대한 연령집단간오류패턴별 비율 비교

초성에서 탄설음/리 산출 시 각 연령집단에서 나타난 오류패턴 별 비율에 대한 기술통계는 Appendix 5 와 같다. 반복측정분산분석 결과, 오류패턴에 대한 주효과가 유의하였고 $\left(F_{(2.311,843.479)}=101.300\right.$, $p<.001)$, 오류패턴과 연령집단 간 상호작용효과가 유의하였다 $\left(F_{(18.487,843.479)}=6.957, p<.001\right)$. 오류패턴의 주효과에 대한 사후검정 결과, 약화는 나머지 오류패턴들보다, 대치는 생략과 활음화보다, 생략은 활음화보다 유의하게 많이 발생하였다 $(p<.001)$. 오류패턴 과 연령집단 간 상호작용효과에 대한 사후검정 결과, 2 세 후반에는 생략과 대치가 나머지 오류패턴들에 비해 유의하게 많았고( $p<.05)$,
활음화가 설측음화보다 유의하게 많았다 $(p<.001)$. 그러다가 3 세 전반부터 5 세 후반에 이르기까지 대치와 약화 간 차이가 유의하지 않은 채 두 오류패턴이 나머지 오류패턴들보다 유의하게 많아졌다 ( $p<.01)$. 나머지 오류패턴들은 대략 생략, 활음화, 설측음화 순이었 고, 그 내에서는 근소하게 그 차이가 유의하거나 또는 유의하지 않 았다. 6세에 와서는 약화가 대치를 포함한 다른 오류패턴들보다 유 의하게 많아졌고, 이는 7세에도 유효하였다 $(p<.001)$ (Figure 7).

설측음/리에 대한 연령집단간 오류패턴별 비율 비교

설측음 /리 산출 시 나타난 각 연령집단의 오류패턴별 비율에 대한 기술통계는 Appendix 5 와 같다. 소수의 아동만 오류를 보인 5 세 전반 이후 집단은 설측음 분석에서 제외하였다. 반복측정분산분 석 결과, 오류패턴에 대한 주효과가 유의하였고 $\left(F_{(2.105,277.853)}=48.759\right.$, $p<.001)$, 오류패턴과 연령 간 상호작용효과가 유의하였다 $\left(F_{(8.420,277.853)}\right.$ $=2.351, p<.001)$. 오류패턴의 주효과에 대한 사후검정 결과, 생략 은 나머지 오류패턴들보다, 약화와 활음화는 대치보다 유의하게 많 았으나 $(p<.01)$, 약화와 활음화의 차이는 유의하지 않았다 $(p>.05)$. 오류패턴과 연령집단 간 상호작용효과에 대한 사후검정 결과, 2 세 후반과 3 세 전반에서는 생략이 다른 오류패턴들보다 $(p<.001)$, 활 음화가 대치보다 유의하게 많았고( $p<.05), 3$ 세 후반에서는 생략이 다른 오류패턴들보다, 약화가 대치보다 유의하게 많았다 $(p<.05)$. 그러다가 4 세 전반에 와서 생략과 약화 간 차이가 유의하지 않아졌 고, 이는 4세 후반에도 여전히 유효하여 두 오류패턴은 나머지 오
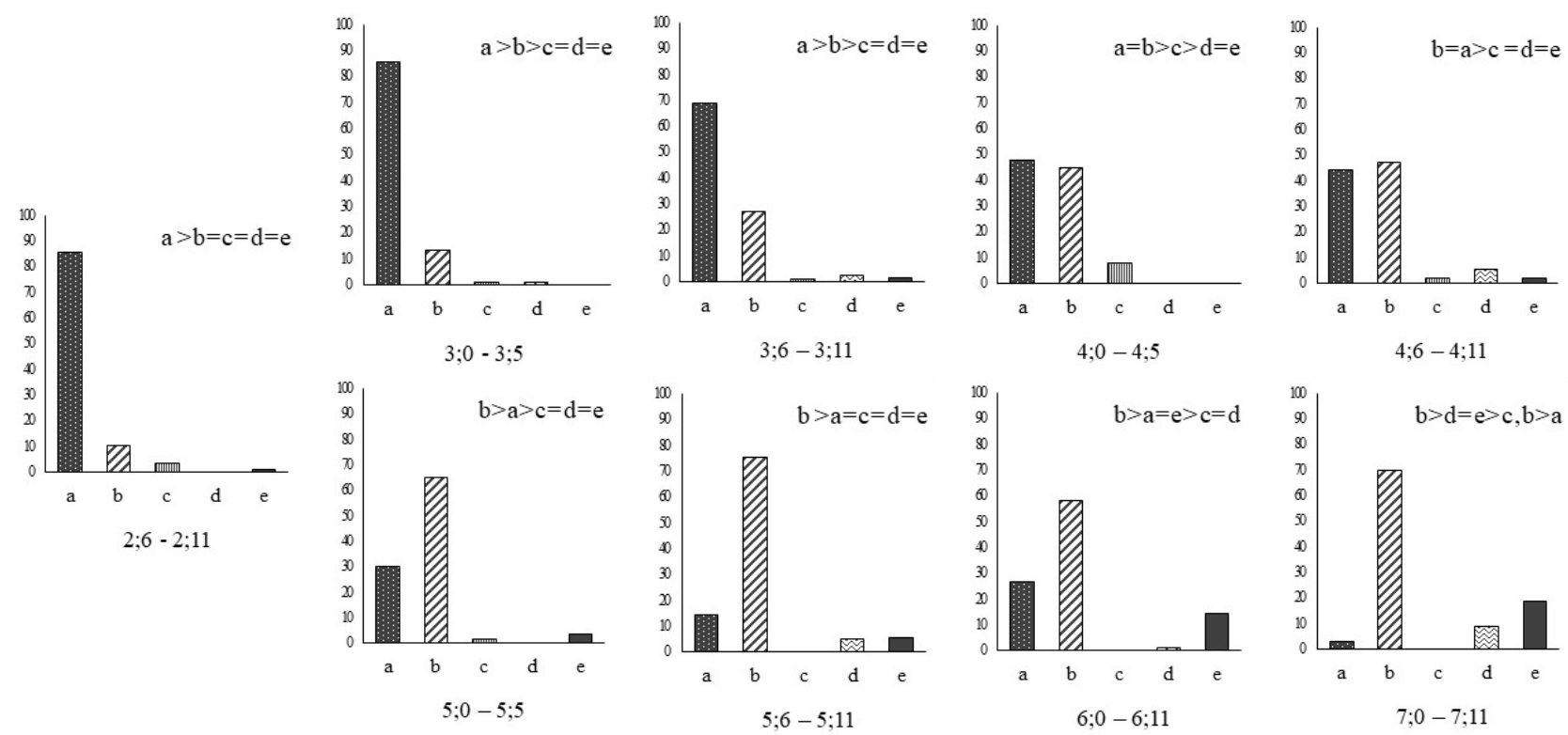

Figure 6. The rates of error patterns in $/ \mathrm{s}^{*} /$ by age groups.

$\mathrm{a}=$ substitution; $\mathrm{b}=$ dentalization/interdentalization; $\mathrm{c}=$ palatalization; $\mathrm{d}=$ lateralization; $\mathrm{e}=$ = weakening. 

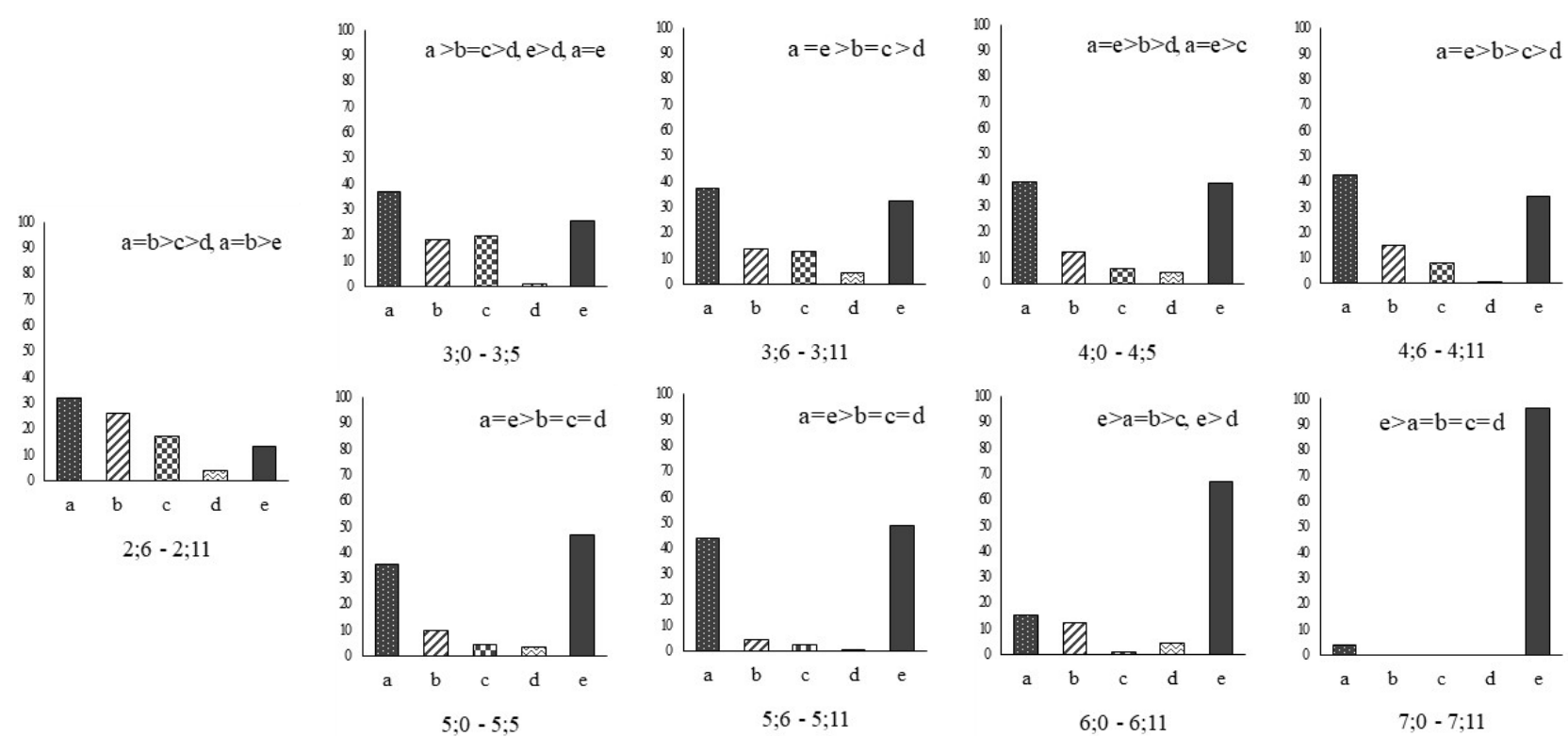

Figure 7. The rates of error patterns in $/ \mathrm{r} /$ by age groups.

$a=$ substitution; $b=$ deletion; $c=$ gliding; $d=$ lateralization; $e=$ weakening.
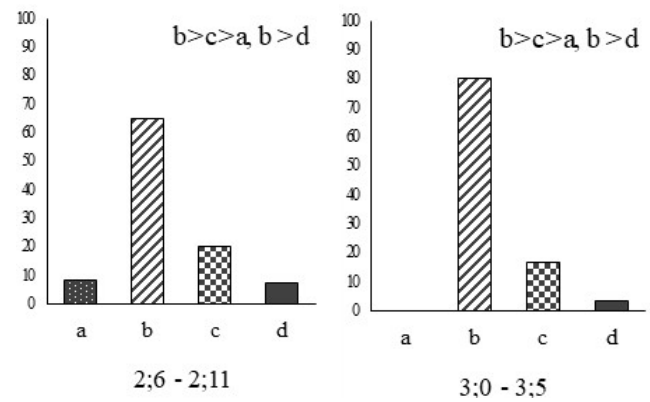

$3 ; 0-3 ; 5$
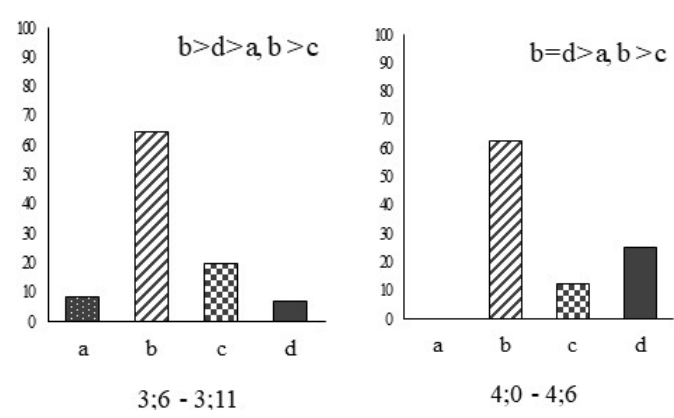

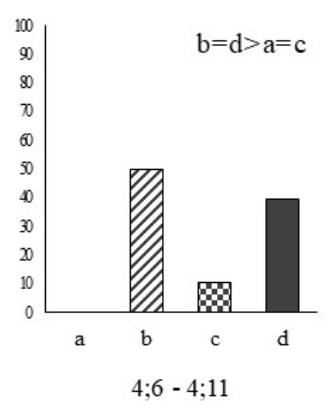

Figure 8. The rates of error patterns in /// by age groups. $\mathrm{a}=$ substitution; $\mathrm{b}=$ deletion; $\mathrm{c}=$ gliding; $\mathrm{d}=$ = weakening .

류패턴들보다 유의하게 많았다( $p<.05$ ) (Figure 8). 이후 5세 전반 부터는 어떤 방식으로든 오류를 보이는 아동이 거의 없었다.

\section{논의 및 결론}

본 연구에서는 2 세 후반부터 7세까지 아동들의 파찰음, 마찰음, 유음의 산출 시 오류율을 살펴보고, 왜곡 오류를 중심으로 오류패 턴을 분석하여 말소리의 발달과정을 살펴보았다. 그 결과 연령이 증가함에 따라 오류율이 유의하게 감소하였고, 각 말소리 별로 연 령에 따른 오류패턴의 변화 양상을 확인할 수 있었다. 우선 오류율 에 대한 결과를 심층적으로 살펴보면, 연령이 증가하면서 대략적 으로 설측음 /ㄹ/, 파찰음, 탄설음 /ㄹ/, 마찰음 순으로 오류율이 낮
아져, 이와 같은 순서로 해당 말소리들이 발달한다고 볼 수 있다. 설 측음/리는 4 세 전반에, 파찰음 중 / ㅉ/는 3 세 후반부터 5 세 전반에 걸쳐, / ㅈ/와/ㅊ/는 4 세 후반에, 탄설음/리와 마찰음은 5 세 전반에 안정기에 도달하였다. 안정기 이전에는 6 개월에서 1 년이라는 길지 않은 시간마다 말소리 발달이 매우 급격하게 일어나, 2세 후반 약 $63 \%$ 에서 $90 \%$ 에 달하던 오류가 5 세 전반에는 약 $6 \%$ 에서 $34 \%$ 까지 소거됨을 알 수 있다(Appendix 2). 이 중 마찰음은 다른 말소리에 비해 서서히 오류율이 줄어들고 7세에도 여전히 $27 \%$ 가 넘는 오류 가 남아 있었는데(Appendix 2), 이는 우리 말소리 가운데 마찰음이 가장 늦게까지 발달하는 음소임을 다시 한 번 상기시켜 준다.

$\mathrm{Ha}$, Kim, Kim과 Shin (2019)의 연구에서도 본 연구와 유사하게 5세 전반에 들어서면 말소리 발달이 안정기에 진입함을 언급한 바 
있다. 그러나 Ha, J. W. 등(2019)의 연구와 본 연구의 '안정기'에는 중 요한 차이점이 있는데, 전자의 경우 만점에 가까운 천정점에 도달 하여 더 이상 변화가 불가능하였던 반면, 후자에서는 여전히 오류 율이 남아있지만 더 이상 변화가 일어나지 않았다는 점이다. 즉, 본 연구의 안정기에는 여전히 고쳐지지 않는 오류가 남아있으나, 연령 이 증가해도 더 이상 그 오류가 유의하게 줄어들지 않음을 간과해 서는 안 될 것이다. Ha, J. W. 등(2019)의 연구가 특정 말소리가 아닌 한국어의 전체 말소리 발달을 종합적으로 살펴보았다는 점, 왜곡 오류에 초점을 둔 연구가 아니기 때문에 본 연구처럼 왜곡을 민감 하게 분석하지 않았을 가능성 등에서 이와 같은 차이가 초래된 이 유를 생각해볼 수 있다. 다시 말해 한국어에서 가장 조음 난이도가 높은 특정 말소리들에 대해 미세하게 목표 소리를 벗어난 왜곡 반 응까지 민감하게 분석할 경우, 말소리 발달의 완성이 7세까지도 완 전히 완료되는 것은 아님을 본 연구결과는 시사하고 있다. 그렇다 면 이 말소리들에서 연령에 따라 오류의 양상이 어떻게 변화해가 는지, 즉 어떤 과정을 거쳐 목표 소리에 근접해가는지를 살펴볼 필 요가 있다. 이를 위해 본 연구의 오류패턴과 연령집단 간 상호작용 효과에 관한 결과를 중점적으로 살펴보고자 한다.

파찰음의 경우/ㅈ/와/ㅊ/는 오류패턴의 발달 양상이 매우 유사 하였다. / 지는 3 세 전반까지, /ㅊ/는 2세 후반에 대치 오류를 가장 많이 보였고, 이후 5 세 전반까지 대치와 파열음화를 둘 다 많이 보 이다가, 5 세 후반 이후에는 오류의 대부분이 파열음화였다. 반면 /찌는 2세 후반부터 대치와 파열음화를 둘 다 많이 보였고, 이미 4 세 전반에 파열음화가 대치보다 많이 나타나기 시작하였다. 대치에 서 파열음화로 변화하는 오류패턴의 발달 양상은 파찰음에 대해 아동이 겪는 조음의 어려움을 짐작하게 해준다. 즉, 치경파열음으 로의 오조음이 대치 오류의 대부분이었던 만큼 말소리 습득 초반 에 위치와 방법적 혼란을 함께 겪은 후, 점차 경구개로의 위치는 안 정되지만 여전히 조음방법적 어려움이 남아있어 경구개에서 파열 음을 산출하는 왜곡을 보인다고 할 수 있다. 파열음은 확실한 폐쇄 후 순간적 개방이 이루어지는 반면, 파찰음은 짧은 폐쇄 후 서서히 개방이 이루어진다(Shin, 2000). 짧은 폐쇄와 지연 개방이라는 조 음방법적 어려움은 아동에게 오랫동안 부담스러운 과제인 듯하다. 반면 / ㅉ/의 경우 3세부터 안정기에 들어서기 시작하여 7세에는 오 류를 보이는 아동이 거의 없었고, 파열음화 오류패턴이 좀 더 어린 연령부터 높은 비중을 차지하는 것으로 미루어 보다 일찍부터 조 음위치를 터득하여 조음방법에 대해서만 어려움을 보였음을 알 수 있다. 이는 / ㅈ/와 /ㅊ/보다 / ㅉ/의 습득이 상대적으로 수월하다는 것을 시사한다. 이는 폐쇄구간이 가장 긴 경음 / ㅉ/ (Shin, 2000)가 '짧은' 폐쇄와 '지연' 개방이라는 시간 조절의 문제에 있어 평음 /ㅈ/
와 격음/치보다 조금은 자유롭고, 그로 인해 아동들에게 산출이 좀 더 용이하기 때문일 가능성을 생각해볼 수 있다.

마찰음에서 / 시와 / 씨의 오류패턴 발달 과정은 거의 동일하였 다. 3 세 후반까지 대치가 가장 많았고, 4 세 전반부터 후반까지 대치 만큼 치간음화가 많아지다가, 5 세 전반 이후 치간음화의 비율이 가 장 많았다. 이러한 마찰음의 발달 양상은 선행연구의 결과(Cheon \& Lee, 1999)와 일치한다. 조음위치와 조음방법을 둘 다 충족시켜 야 하는 부담스러운 과제에서, 마찰음은 파찰음과 달리, 아동으로 하여금 조음방법을 유지하고 위치를 포기하게 하였다. 이에 대해서 는 마찰성 소음이라는 마찰음의 두드러지는 지각적 특성이 조음방 법에 우선 순위를 둔 오조음 방식에 영향을 주었을 가능성을 생각 해볼 수 있다. 더불어 $27 \%$ 가 넘는 오류율을 여전히 보이는 7세에서 도 대부분의 오류가 치간음화였다는 점을 감안할 때, 치경마찰음 의 치간음화는 4 세 전반부터 나타나기 시작하여 매우 오랫동안 지 속되는 오류임을 알 수 있다. 이와 비슷한 결과들이 여러 선행연구 들에서 보고된 바 있으며(Kim, 2006; Smit, 1993), 특히 말소리장애 아동의 경우 치경마찰음의 치간음화는 자발적으로 제거되기 어려 운 오류패턴이므로 적절한 시기에 중재를 제공해야 함을 주장한 연구도 찾아볼 수 있다(Dodd et al., 2018).

유음의 경우 탄설음/리와 설측음 /리의 오류패턴 발달 양상은 다소 상이하였다. 설측음/리를 먼저 살펴보면 3세 후반까지는 생 략이, 4 세 전반과 후반은 생략과 약화가 주로 나타나다가 5 세 전반 부터는 오류를 보이는 아동이 거의 없었다. 종성에서 /리의 생략이 빈번하다는 것은 Choi와 Kim (2013)에서도 언급된 바 있다. 설측 음/리는 음향학적으로 모음과 유사하지만 이웃모음보다는 강도 가 약해 모음 다음에 산출되는 경우/리를 확실하게 발음하지 않으 면 지각에 어려움이 있을 수 있다(Kenney \& Prather 1986). 이러한 선행연구에 근거할 때 어린 연령에서 나타나는 생략은 아동의 청지 각적 어려움이 불명확한 산출로 연결되었을 가능성, 혹은 그 반대 의 경우로 약화 등의 왜곡 오류를 검사자가 생략으로 잘못 분류했 을 가능성 등을 생각해볼 수 있다. 또한 실험 단어에 포함된 '연필' 의 경우 설측음/리를 활음 $/ \mathrm{j} /$ 로 오조음하더라도 / $/$ 모음 뒤에서는 생략으로 지각되기 때문에, 활음화 또한 생략으로 분류되었을 가 능성도 배제할 수 없다. 이러한 가능성들을 고려할 때 청지각적 판 단에만 의존하여 왜곡 오류를 분석한 본 연구의 방법적 제한점을 부정할 수 없으며, 따라서 음향학적 분석 등으로 이를 보완한 추후 연구가 요구된다.

마지막으로 탄설음은 2 세 후반에는 생략과 대치를, 3 세 후반부 터 5세 후반까지는 대치와 약화를, 6세 이후부터는 약화를 가장 많 이 보였다. 탄설음의 약화에는 혀가 치경에 확실히 닿지 않았거나 
약간 후방화된 채 혀가 입천장에 확실히 닿지 않았거나 폐쇄의 지 속시간이 다소 길어졌으나/디보다는 약한 경우 등 다양한 오류가 포함되었다. 이러한 오류들은 공통적으로 혀와 입천장의 적절한 접 촉을 위한 운동범위, 힘 또는 시간 조절의 실패를 내포하고 있으며, 이는 탄설음의 성공적인 조음을 위한 민첩하고 균형 잡힌, 즉 상당 히 수준 높은 운동조절에 대해 높은 연령의 아동들조차도 부담스 러워 하고 있음을 시사한다. 파찰음과 더불어 탄설음의 조음은 짧 은 시간 내에 이루어지는 운동조절능력을 평가하기에 적합한 말소 리이며, 따라서 이에 대한 왜곡 오류가 특정 연령대 이후에도 지속 된다면 이는 운동조절능력의 미성숙을 반영한다고 할 수 있다.

정리하면 파찰음은 대치, 파열음화의 과정을, 마찰음은 대치, 치 간음화의 과정을, 유음은 생략, 대치, 약화의 과정을 거쳐 목표 말소 리에 근접해간다. 무엇보다 본 연구결과로 얻은 가장 큰 수확은 왜 곡까지 포함하여 오류를 분석할 경우 말소리의 습득이 7세까지도 완벽하게 완성되는 것은 아니라는 점이다. 그러나 또 한편으로는 정상 성인의 경우도 왜곡이 전혀 없는 완벽한 발음을 구사하는지, 만일 그렇지 않다면 왜곡 오류를 어느 선까지 정상 범주로 판단하 여야 하는지에 대해 의문이 생긴다. 또한 왜곡 오류는 의사소통실 패를 초래하지도, 명료도에 크게 부정적 영향을 미치지도 않으니 관대하게 수용해야 하는 것인지, 아니면 말소리의 질을 떨어뜨림으 로써 얻게 될 부정적 측면들을 사전에 배제하기 위해 엄격하게 평 가하고 적극적으로 개입해야 하는 것인지에 대해서도 생각해볼 문 제이다. 이에 대해 말소리를 다루는 언어치료전문인들 사이에는 어 느 정도의 합의가 필요할 듯 하다.

더불어 조음 난이도가 높은 말소리에 대해 5 세 전반 이후의 일반 아동들도 어느 정도 어려움이 있다는 본 연구결과는 조음운동능 력이 미성숙한 말소리장애 아동에게 해당 말소리를 산출하는 것이 얼마나 부담스러운 과제일지 짐작하게 해준다. 일반 아동의 경우도 파찰음, 마찰음, 유음의 정확한 조음은 여러 왜곡 오류를 거쳐 완성 되는, 생각보다 긴 여정이었으며, 따라서 본 연구결과 얻게 된 왜곡 오류패턴의 발달 과정은 말소리장애 아동의 중재 시 목표 음소를 향해 점진적인 접근을 유도하는 데에도 유용한 정보를 제공할 것 으로 기대한다.

그러나 이와 같은 의의에도 불구하고 본 연구는 방법적 측면에 서 몇 가지 제한점이 있다. 앞에서 언급하였던 청지각적 분석의 한 계와 더불어 왜곡 판단에 대한 검사자 간 신뢰도의 문제를 덧붙일 수 있다. 왜곡 오류는 말소리 분석에 대한 검사자의 경험, 청지각적 민감성 등에 크게 좌우되기 때문에, 동일한 반응에 대해 검사자마 다 다른 판단을 하기가 쉽다. 본 연구에서도 두 연구자 간 6 개월 간 의 집중적 연습과 논의 기간을 거친 후 가까스로 $80 \%$ 이상의 신뢰
도에 도달할 수 있었다. 말소리에 대한 빈번한 노출은 청지각적 민 감성을 높이고, 이는 보다 정확하고 정밀한 평가로 연결될 수 있다. 왜곡 오류는 말소리장애 아동의 운동적 결함을 파악하는 데에 중 요한 정보를 제공하는 만큼, 언어치료전문가는 아동의 왜곡 반응 에 대한 빈번한 노출과 경험을 통해 보다 민감한 지각 능력을 갖추 어야 할 것이다.

또한 각 말소리에 대해 소수의 단어 항목으로 실험을 진행하였 다는 점에서도 연구의 제한점이 있다. 정해진 단어 검사항목을 이 용하였기 때문에 다양한 문맥에서 말소리 산출을 유도하는 것이 불가능하였고, 산출 기회도 제한적이었다. 보다 타당한 연구결과 를 도출하기 위해 다양한 문맥에서 여러 차례 산출을 유도할 수 있 는 잘 계획된 실험과제를 사용하지 못하였던 점에 대해 연구자들 또한 아쉬움이 많다. 그러나 그럼에도 불구하고 2세부터 7세까지 말소리 발달의 전 연령대를 아우르는 전국 규모의 아동들을 대상 으로 인내심을 요하는 분석 과정에 도전하여, 학술적인 근거가 부 족하였던 왜곡 오류패턴의 발달 과정에 대해 의미 있는 정보를 얻 었다는 점에서 그 의의를 찾고자 한다.

\section{REFERENCES}

Cheon, H. J., \& Lee, S. H. (1999). The development of Korean $/ \mathrm{s} /$ and $/ \mathrm{s}^{\star} /$ in normal children of ages 2-7 years. The Korean Journal of Communication Disorders, 4, 1-24.

Choi, M. S., \& Kim, S. J. (2013). Morphological influences on liquid acquisition in Korean children's spontaneous speech. Korean Journal of Communication \& Disorders, 18(1), 76-85.

Dodd, B., Ttofari-Eecen, K., Brommeyer, K, Reilly, S., \& Morgan, A. (2018). Delayed and disordered development of articulation and phonology between four and seven years. Child Language Teaching and Therapy, 34(2), 87-99.

Ha, J. W., Kim, S. J., Kim, Y. T., \& Shin, M. J. (2019). Developmental analysis in Korean children's speech production using percentage of consonants correct and whole-word measurements. Communication Sciences \& Disorders, 24(2), 469-477.

Ha, S. H., Kim, M. J., \& Pi, M. K. (2019). Percentage of consonants correct and age of acquisition of consonants in Korean-speaking children in onesyllable word contexts. Communication Sciences \& Disorders, 24(2), 460468.

Howell, R. B. (1991). Old English breaking and its Germanic analogues. Tubingen: Niemeyer. 
Kenney, K. W., \& Prather, E. M. (1986). Articulation development in preschool children: consistency of productions. Journal of Speech, Language, and Hearing Research, 29(1), 29-36.

Kim, M. J. (2006). The phonological error patterns of preschool children in the 'Korean Test of Articulation for Children'. Korean Journal of Communication \& Disorders, 11(2), 17-31.

Kim, M. J., \& Pae, S. Y. (2005). The percentage of consonants correct and the ages of consonantal acquisition for 'Korean-Test of Articulation for Children (K-TAC)'. Speech Sciences, 12(2), 139-149.

Kim, S. J., \& Shin, J. Y. (2015). Speech sound disorders. Seoul: Sigma Press.

Kim, Y. T. (1996). The percentage of correct consonants in preschoolers used by Picture Articulation Test. The Korean Journal of Communication Disorders, 1(1), 7-33.

Kim, Y. T., Hong, G. H., Kim, K. H., Chang, H. S., \& Lee, J. Y. (2009). Receptive \& expressive vocabulary test (REVT). Seoul: Seoul Community Rehabilitation Center.
Kim, Y. T., Shin, M. J., Kim, S. J., \& Ha, J. W. (2020). Urimal Test of Articulation and Phonology 2 (UTAP2). Seoul: Hakjisa.

Koch, C. L. (2018). Clinical management of speech sound disorders: a casebased approach. Burlington, MA: Jones \& Bartlett Learning.

McLeod, S., \& Crowe, K. (2018). Children's consonant acquisition in 27 languages: a cross-linguistic review. American Journal of Speech-Language Pathology, 27(4), 1546-1571.

Oum, J. H. (1986). Speech-sound development in children aged three to five years in Korean: with special reference to consonants (Master's thesis). Ewha Womans University, Seoul. Korea.

Oum, J. H. (1994). Normal speech development (II). Seoul: Koonja publishing inc.

Shin, J. Y. (2000). Understand of speech sound. Seoul: Hankookmunhwasa.

Smit, A. B. (1993). Phonologic error distributions in the Iowa-Nebraska articulation norms project: consonant singletons. Journal of Speech, Language, and Hearing Research, 36(3), 533-547. 
Appendix 1. Types and definitions of distortion error patterns used in this study

\begin{tabular}{|c|c|c|}
\hline 말소리 & 왜곡 오류패턴 & 정의 \\
\hline \multirow[t]{3}{*}{ 파찰음 } & 파열음화(stopping) & 경구개 위치에서 조음방법을 파열음으로 산출한 경우 \\
\hline & 설측음화(lateralization) & 개방 시 혀의 측면 통로로 기류를 서서히 방출한 경우 \\
\hline & 약화(weakening) & $\begin{array}{l}\text { 폐쇄가 불확실하여 마치 생략처럼 들리기도 하지만 혀의 상승으로 인한 구강 중앙부의 방해 자체는 지각할 } \\
\text { 수 있는 경우 }\end{array}$ \\
\hline \multirow[t]{4}{*}{ 마찰음 } & 치간음화(dentalization/interdentalization) & 조음위치가 전방화되어 치음 또는 치간에서 산출한 경우 \\
\hline & 경구개음화(palatalization) & 조음위치가 후방화되어 경구개에서 산출한 경우 \\
\hline & 설측음화(lateralization) & 개방 시 혀의 측면 통로로 기류를 서서히 방출한 경우 \\
\hline & 약화(weakening) & 치경 위치에서 마찰성 소음이 약하여 마치 생략과 성문마찰음/ㅎ/의 중간소리처럼 지각되는 경우 \\
\hline \multirow[t]{3}{*}{ 유음 } & 활음화(gliding) & 유음 대신 활음/j/로 지각되는 경우 \\
\hline & 설측음화(lateralization) & 탄설음 산출 시 혀 중앙의 치경 접촉기간이 다소 길어져 설측음처럼 지각되는 경우 \\
\hline & 약화(weakening) & $\begin{array}{l}\text { 혀가 치경에 확실히 닿지 않은 경우, 약간 후방화된 채 여전히 혀가 입천장에 확실히 닿지 않아 권설음 } \\
\text { (retroflex)처럼 들리는 경우, 폐쇄의 지속시간이 다소 길어졌으나 / 디보다는 약한 소리로 지각되는 경우 }\end{array}$ \\
\hline
\end{tabular}

Appendix 2. Descriptive statistic results of the error rates by age groups

\begin{tabular}{|c|c|c|c|c|c|c|c|c|}
\hline Age (yr;mo) & $\mid \mathrm{tc}_{6} /$ & $/ \mathrm{tch} /$ & $\left|\mathrm{tc}_{\varphi}^{*}\right|$ & /s/ & $/ s^{*} /$ & $/ \mathrm{r} /$ & /I/ & $\mid \mathrm{tc}_{6} /$ \\
\hline $2 ; 6-2 ; 11(\mathrm{~N}=59)$ & $69.83(28.13)$ & 59.75 (35.05) & 72.46 (36.76) & $90.67(25.00)$ & $90.96(22.17)$ & $85.87(20.95)$ & 63.56 (38.09) & 69.83 (28.13) \\
\hline $3 ; 0-3 ; 5(N=54)$ & 58.70 (34.51) & 57.87 (34.96) & 61.11 (38.44) & $85.19(31.50)$ & 85.80 (28.67) & 79.94 (23.88) & 38.89 (35.91) & 38.89 (35.91) \\
\hline $3 ; 6-3 ; 11(\mathrm{~N}=57)$ & 33.33 (35.72) & 30.26 (36.82) & $28.07(38.40)$ & $66.08(44.76)$ & $62.57(37.83)$ & 55.26 (37.02) & $24.56(30.06)$ & 33.33 (35.72) \\
\hline $4 ; 0-4 ; 5(N=65)$ & 29.54 (31.84) & 29.23 (32.04) & 37.69 (43.33) & $59.49(42.28)$ & 60.51 (38.59) & 47.69 (34.85) & $10.77(24.19)$ & 29.54 (31.84) \\
\hline $4 ; 6-4 ; 11(\mathrm{~N}=70)$ & 24.57 (31.79) & 20.00 (31.74) & $31.43(40.53)$ & $56.67(42.60)$ & $57.24(40.46)$ & 45.71 (37.18) & 17.86 (31.89) & 24.57 (31.79) \\
\hline $5 ; 0-5 ; 5(N=50)$ & $9.60(23.3)$ & $13.00(27.31)$ & $12.00(27.31)$ & $32.67(38.97)$ & 34.67 (33.65) & $23.33(29.55)$ & $6.00(16.41)$ & $9.60(23.3)$ \\
\hline $5 ; 6-5 ; 11(\mathrm{~N}=73)$ & $18.63(26.10)$ & $15.75(27.17)$ & 20.21 (31.36) & 35.39 (38.88) & 31.51 (35.53) & $18.77(24.77)$ & 3.42 (12.72) & $18.63(26.10)$ \\
\hline $6 ; 0-6 ; 11(\mathrm{~N}=82)$ & 13.66 (24.52) & $9.45(21.39)$ & $9.45(24.10)$ & $27.03(35.78)$ & 24.80 (32.63) & $14.23(24.86)$ & 3.66 (15.28) & 13.66 (24.52) \\
\hline $7 ; 0-7 ; 11(\mathrm{~N}=46)$ & 9.57 (17.76) & 6.52 (17.03) & $4.89(17.97)$ & 27.54 (33.92) & 24.64 (36.13) & $6.16(15.85)$ & 1.09 (7.37) & 9.57 (17.76) \\
\hline Total $(\mathrm{N}=556)$ & $29.19(34.60)$ & 26.17 (34.73) & 30.40 (40.07) & 52.61 (43.72) & $51.63(41.52)$ & 41.04 (38.83) & $18.17(31.80)$ & 29.19 (34.60) \\
\hline
\end{tabular}

Values are presented as mean (SD). 


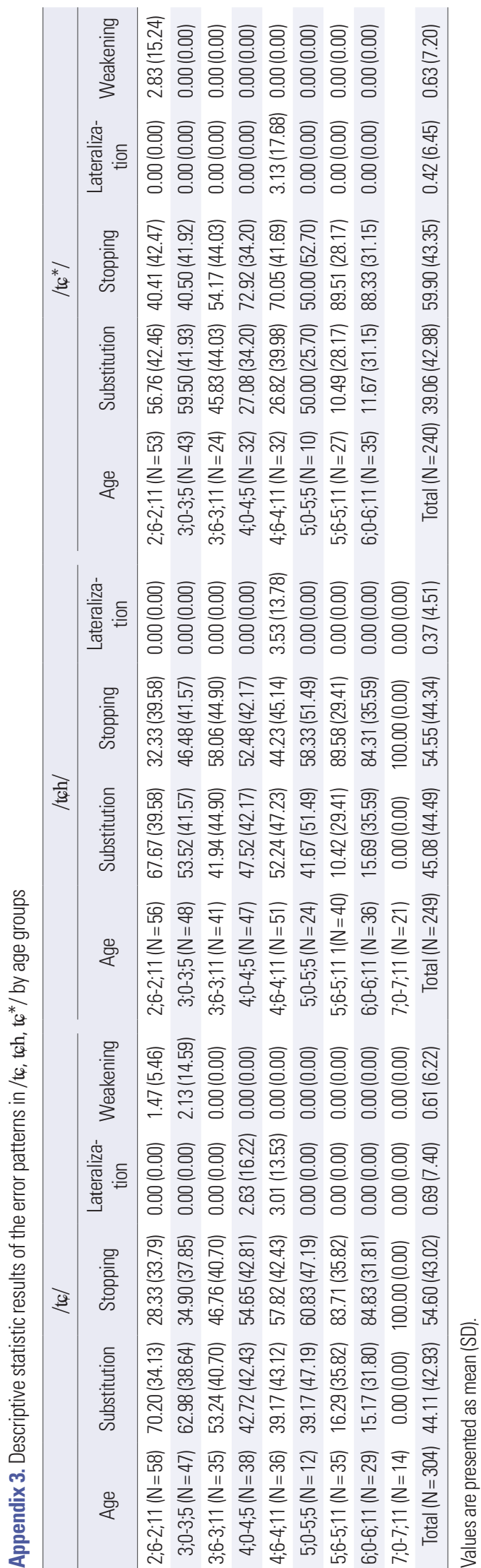

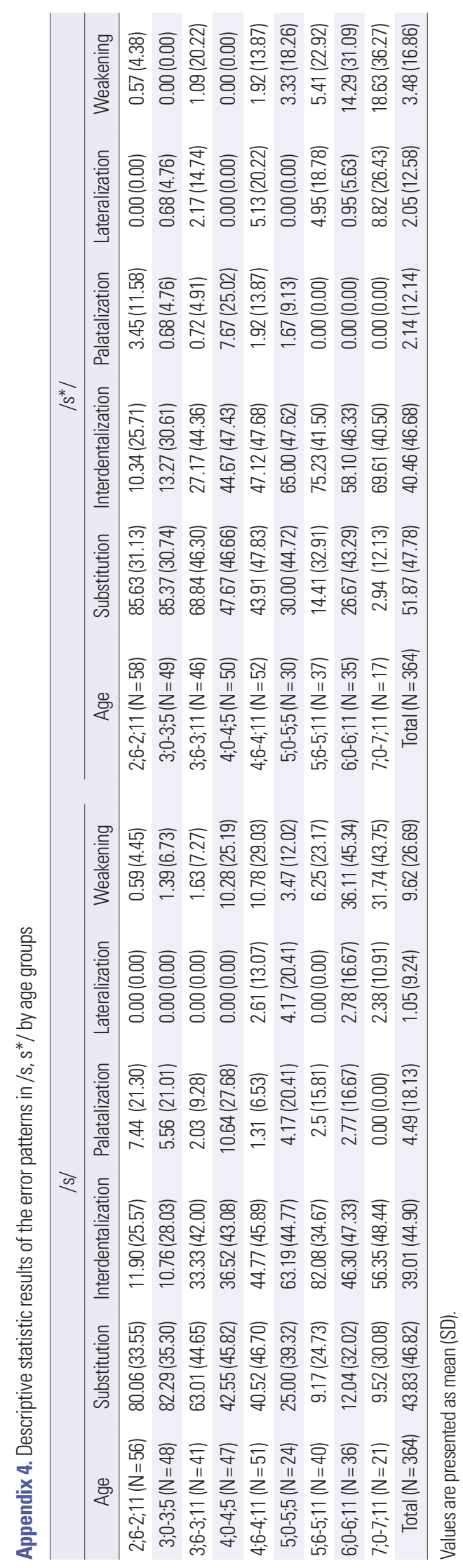

https://www.e-csd.org 


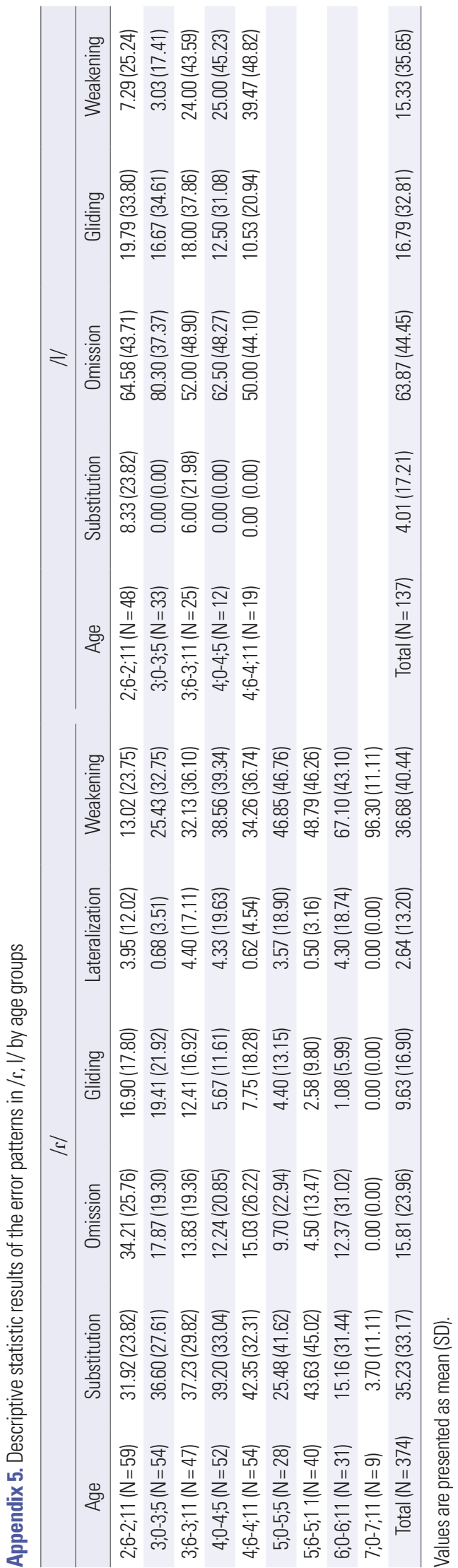




\section{국문초록}

\section{파찰음, 마찰음, 유음의 왜곡 오류에 대한 발달 연구}

김미진 ${ }^{\prime}$ 류은주 ${ }^{12} \cdot$ 하지완 ${ }^{13}$

'대구대학교 일반대학원 재활과학과 언어치료전공, ${ }^{2}$ 위덕대학교 언어청각치료학과, ${ }^{3}$ 대구대학교 언어치료학과

배경 및 목적: 우리나라 말소리에서 가장 늦게 습득하며, 많은 오류를 보이는 말소리인 파찰음, 마찰음, 유음의 오류율과 오류패턴에 대 한 발달 과정을 살펴보고자 하였다. 방법: 2 세 후반부터 7 세의 일반아동 556 명을 대상으로 UTAP2의 단어수준 검사를 실시하였다. 그 중 파찰음, 마찰음, 유음이 포함된 단어의 산출 시 나타나는 오류율과 오류패턴 별 비율을 산출한 후 연령집단 간 비교하였다. 결과: 첫 째, 연령이 증가함에 따라 모든 말소리에서 오류율이 유의하게 감소하였고, 말소리 별로는 설측음/ㄹ/, 파찰음, 탄설음/리, 마찰음 순으 로 감소하였다. 둘째, 연령의 증가에 따른 오류패턴의 분포의 변화를 살펴본 결과, 파찰음은 대치, 파열음화의 과정을, 마찰음은 대치, 치 간음화의 과정을, 유음은 생략, 대치, 약화의 과정을 거쳐 목표 말소리에 접근함을 알 수 있었다. 논의 및 결론: 일반아동의 경우도 파찰 음, 마찰음, 유음의 정확한 조음은 여러 왜곡 오류를 거쳐 완성되는, 생각보다 긴 여정이었다. 말소리 발달의 전 연령대를 아우르는 전국 규모의 아동들을 대상으로, 학술적 근거가 부족하였던 왜곡 오류패턴의 발달 과정을 파악하였다는 점에서 연구의 의의가 있을 것이다. 이는 말소리장애 아동의 중재 시 목표 음소를 향해 점진적인 접근을 유도하는 데에도 유용한 정보를 제공할 것이다.

핵심어: 파찰음, 마찰음, 유음, 왜곡 오류, 말소리 산출 오류율, 오류패턴

이 논문은 2019년 대한민국 교육부와 한국연구재단의 지원을 받아 수행된 연구임(NRF-2019S1A5A2A03054267).

\section{참고문헌}

김민정(2006). ‘아동용 조음검사’에 나타난 취학 전 아동의 음운오류패턴. 언어청각장애연구, 11(2) 17-31. 김민정, 배소영(2005) ‘아동용 조음검사’를 이용한 연령별 자음정확도와 우리말 자음의 습득연령. 음성과학, 12(2), 139-141.

김수진, 신지영(2015). 말소리장애. 서울: 시그마프레스.

김영태(1996). 그림자음검사를 이용한 취학전 아동의 자음정확도 연구. 말-언어장애연구, 1(1), 7-33.

김영태, 신문자, 김수진, 하지완(2020). 우리말 조음음운평가2 (UTAP2). 서울: 학지사

김영태, 홍경훈, 김경희, 장혜성, 이주연(2009). 수용·표현어휘력검사(REVT). 서울: 서울장애인종합복지관.

신지영(2000). 말소리의 이해. 서울: 한국문화사.

엄정희(1986).3·4·5세 아동의 말소리 발달에 관한 연구: 자음을 중심으로. 이화여자대학교 대학원 석사학위논문.

엄정희(1994). 정상 말소리 발달(II). 서울: 군자출판사.

전희정, 이승환(1999). 2-7세 정상아동의/ㅅ/와/씨 말소리 발달 연구. 언어청각장애연구, 4, 1-24.

최민실, 김수진(2013). 자발화에 나타난 3-4세 아동의 형태소 유형별 유음 발달 특성. 언어청각장애연구, 18(1), 76-85.

하승희, 김민정, 피민경(2019). 일음절 낱말 과제에서 살펴본 한국 아동의 자음정확도와 습득 연령. Communication Sciences \& Disorders, 24(2), 460-468.

하지완, 김수진, 김영태, 신문자(2019). 자음정확도와 단어단위 음운지표를 이용한 일반아동의 말소리산출 능력에 대한 발달 연구. Communication

Sciences and Disorders, 24(2), 469-477.

\section{ORCID}

김미진(제1저자, 대학원생 https://orcid.org/0000-0002-2151-6167); 류은주(공동저자, 초빙교수, 대학원생 https://orcid.org/0000-0002-8233-6995); 하지완(교신저자, 교수 https://orcid.org/0000-0002-1191-791X) 